University of Pennsylvania Carey Law School

Penn Law: Legal Scholarship Repository

Faculty Scholarship at Penn Law

$11-2007$

\title{
The Short and Puzzling Life of the "Implicit Minority Discount" in Delaware Appraisal Law
}

Lawrence A. Hamermesh

Widener University School of Law

Michael L. Wachter

University of Pennsylvania Carey Law School

Follow this and additional works at: https://scholarship.law.upenn.edu/faculty_scholarship

Part of the Banking and Finance Law Commons, Business Organizations Law Commons, Corporate Finance Commons, and the Law and Economics Commons

\section{Repository Citation}

Hamermesh, Lawrence A. and Wachter, Michael L., "The Short and Puzzling Life of the "Implicit Minority Discount" in Delaware Appraisal Law" (2007). Faculty Scholarship at Penn Law. 134.

https://scholarship.law.upenn.edu/faculty_scholarship/134

This Article is brought to you for free and open access by Penn Law: Legal Scholarship Repository. It has been accepted for inclusion in Faculty Scholarship at Penn Law by an authorized administrator of Penn Law: Legal Scholarship Repository. For more information, please contact PennlawIR@law.upenn.edu. 


\title{
University of Pennsylvania \\ Law Review
}

FOUNDED 1852

Formerly

American Law Register

VOL. 156

NOVEMBER 2007

No. 1

ARTICLES

\section{THE SHORT AND PUZZLING LIFE OF THE "IMPLICIT MINORITY DISCOUNT" IN DELAWARE APPRAISAL LAW}

\author{
LAWRENCE A. HAMERMESH ${ }^{\dagger}$ \& MICHAEL L. WACHTER ${ }^{\dagger}$
}

${ }^{\dagger}$ Ruby R. Vale Professor of Corporate and Business Law, Widener University School of Law; Director, Widener Institute of Delaware Corporate and Business Law.

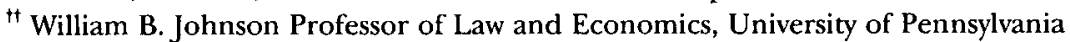
Law School; Co-Director, Institute for Law and Economics at the University of Pennsylvania. The authors gratefully acknowledge the contribution of the criticisms and suggestions made by the Honorable Leo E. Strine, Jr., Robert Holthausen, Andrew Metrick, Bruce Silverstein, and Jessica Wachter, as well as Eric Talley, Jeff Cordon, John Coates, Tom Allingham, Rob Spatt, and other participants in the December 8, 2006 Corporate Finance Roundtable at the Institute for Law and Economics at the University of Pennsylvania, and David Yermack and other participants in the February 23, 2007 Penn/NYU Conference on Law and Finance. The authors in particular are grateful for the insights and superlative research assistance provided by Brent SonnekSčhmelz of the University of Pennsylvania Law School Class of 2006, and Neela Mookerjee of the University of Pennsylvania Law School Class of 2008. As always, none of these helpful individuals is to blame for any ambiguities or outright errors of analysis or fact. 
The "implicit minority discount," or "IMD," is a fairly new concept in Delaware appraisal law. A review of the case law discussing the concept, however, reveals that it has emerged haphazardly and has not been fully tested against principles that are generally accepted in the financial community. While control share blocks are valued at a premium because of the particular rights and opportunities associated with control, these are elements of value that cannot fairly be viewed as belonging either to the corporation or its shareholders. In corporations with widely dispersed shareholdings, the firm is subject to agency costs that must be taken into consideration in determining going concern value. A control-block-oriented valuation that fails to deduct such costs does not represent the going concern value of the firm. As a matter of generally accepted financial theory, on the other hand, share prices in liquid and informed markets do generally represent that going concern value, with attendant agency costs factored or priced in. There is no evidence that such prices systematically and continuously err on the low side, requiring upward adjustment based on an "implicit minority discount."

Given the lack of serious support for the IMD in finance literature, this Article suggests that the Delaware courts may be relying on the IMD as a means to avoid imposing upon squeezed-out minority shareholders the costs of fiduciary misconduct by the controller. Where either past or estimated future earnings or cash flows are found to be depressed as a result of fiduciary misconduct, however, or where such earnings or cash flows fail to include elements of value that belong to the corporation being valued, the appropriate means to address the corresponding reduction in the determination of "fair value" is an upward adjustment to those earnings or cash flows.

This approach to the problem of controller opportunism is more direct, more comprehensive in its application, and more in keeping with prevailing financial principles than the IMD that the Delaware courts have applied in the limited context of comparable company analysis. The Delaware courts can therefore comfortably dispense with resorting to the financially unsupported concept that liquid and informed share markets systematically understate going concern value. 


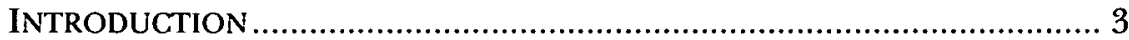

I. WHENCE IMD? ....................................................................... 7

A. The Doctrinal Soil of the IMD: The Backdrop of Delaware Supreme Court Precedent .................................................... 8

B. The Initial Appearance (and Rejection) of the IMD ............... 16

C. The IMD Takes Root .................................................. 17

D. The IMD Goes from Permissible to Mandatory....................... 20

II. THE FINANCE BEHIND DELAWARE APPRAISAL LAW ........................ 24

A. The Value of the Firm .................................................... 24

B. Third-Party Sale Value and Synergies................................ 30

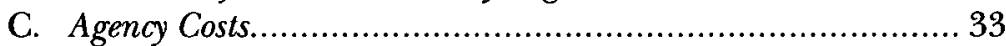

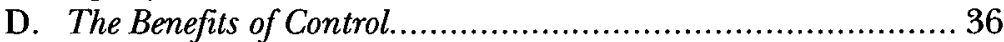

E. Summing Up: The Pratt Diagram..................................... 39

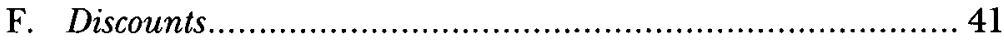

1. Illiquidity Discounts ............................................... 41

2. Closed-End Funds .............................................. 42

3. Nonvoting Stock .................................................... 46

III. THE TREATMENT OF FINANCE IN DELAWARE APPRAISAL LAW......... 47

A. Consistent with Finance, but with One Exception................... 47

B. The Supposed Finance Behind the IMD ............................... 50

C. Why the Delaware Bench and Bar Fell into Error ...................52

IV. Pulling UP THE WEED: DOES ReJECTING THE IMD IMPAIR THE

UTILITY OR FAIRNESS OF THE APPRAISAL REMEDY? ........................ 56

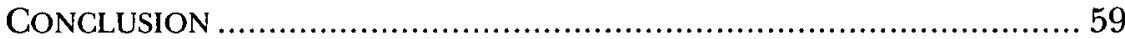

\section{INTRODUCTION}

Our recent article on the subject of share valuation began with the observation that the 1983 Weinberger decision" "revolutionized appraisal law." 2 One of Weinberger's critical (although perhaps longoverdue) contributions was its recognition that in assessing share value in appraisal cases, courts should be guided by "proof of value by any techniques or methods which are generally considered acceptable in the financial community."

For many decades the Delaware courts have embraced a standard of valuation in appraisal cases that awards dissenting stockholders

${ }^{1}$ Weinberger v. UOP, Inc., 457 A.2d 701 (Del. 1983).

${ }^{2}$ Lawrence A. Hamermesh \& Michael L. Wachter, The Fair Value of Cornfields in Delaware Appraisal Law, 31 J. CORP. L. 119, 121 (2005).

${ }^{3}$ Weinberger, 457 A.2d at 713 . 
their proportional share of the value of the "going concern." ${ }^{4}$ In the years after Weinberger admonished that valuation should employ techniques generally acceptable in the financial community, Delaware's "going concern" standard has had a largely happy and fruitful marriage with modern principles of finance. Under those principles, the value of the firm, of which the dissenting stockholders receive a proportionate share, is represented by the net present value of the firm's future free cash flows. ${ }^{5}$ With Weinberger's salutary blessing, this approach to valuation has come to dominate Delaware valuation proceedings. ${ }^{6}$ Most commonly identified as the "discounted cash flow" or "DCF" approach, this valuation approach fits comfortably within the legal parameters of appraisal proceedings. Under those parameters, stockholders in appraisal proceedings, who by statute may not share in the benefits arising from the transaction giving rise to the appraisal proceeding, ${ }^{7}$ do not receive a value that includes synergies or benefits of control; $;$ nor do they receive a value that fails to take into account the agency costs that are part of the corporation's "operative reality" and that are therefore a component of the anticipated free cash flows of the going concern. ${ }^{10}$

${ }^{4}$ E.g., Paskill Corp. v. Alcoma Corp., 747 A.2d 549, 553 (Del. 2000) (citing TriContinental Corp. v. Battye, 74 A.2d 71, 72 (Del. 1950)). For a list of additional recent cases discussing the concept of "going concern value," see Hamermesh \& Wachter, supra note 2, at $132 \mathrm{n} .56$ (citing cases using the term "going concern value").

${ }^{5}$ See discussion infra Part II.A.

${ }^{6}$ See Hamermesh \& Wachter, supra note 2, at 125 n.30 (citing appraisal cases relying on DCF analysis); see also In re PNB Holding Co. S'holders Litig., No. 28-N, 2006 Del. Ch. LEXIS 158, at *95 (Aug. 18, 2006) (selecting the DCF valuation approach over comparable companies and comparable acquisition methods); Del. Open MRI Radiology Assocs. v. Kessler, 898 A.2d 290, 331 (Del. Ch. 2006) (using the DCF valuation method when both parties' experts did); Andaloro v. PFPC Worldwide, Inc., No. 20336, 2005 Del. Ch. LEXIS 125, at*35 (Aug. 19, 2005) (noting the frequent use of the DCF method in Delaware valuation proceedings).

${ }^{7}$ See DEL. CODE ANN. tit. 8, \$ 262(h) (2006) (excluding from "fair value" any elements of value arising from the merger or consolidation giving rise to the appraisal proceeding).

${ }^{8}$ See, e.g., Andaloro, 2005 Del. Ch. LEXIS 125, at *70 n.74 (noting that the going concern value standard requires excluding synergies attributable to business combination); Union Ill. 1995 Inv. Ltd. P'ship v. Union Fin. Group, Ltd., 847 A.2d 340, 356 (Del. Ch. 2003) (“[T]his court must endeavor to exclude from any appraisal award the amount of any value that the selling company's shareholders would receive because a buyer intends to operate the subject company, not as a stand-alone concern, but as a part of a larger enterprise, from which synergistic gains can be extracted.").

${ }^{9}$ Cede \& Co. v. Technicolor, Inc., 684 A.2d 289, 298 (Del. 1996).

${ }^{10}$ Hamermesh \& Wachter, supra note 2, at 139-40. 
As sometimes happens in rapidly developing bodies of law, however, a doctrinal weed sprung up in the late 1990s in what was otherwise a largely harmonious, well-tended garden of finance and law. In a rapid succession of cases over a period of less than ten years, there developed what is now known in the Delaware case law as the "implicit minority discount," or "IMD." It is this recently sprouted concept that is the central focus of this Article.

The financial/empirical assertion of the IMD is quite simple: no matter how liquid and informed the financial markets may be, all publicly traded shares persistently and continuously trade in the market at a substantial discount relative to their proportionate share of the value of the corporation. ${ }^{12}$ This discount, it is said, arises because the stock prices on national securities markets represent "minority" positions, and minority positions trade at a discount to the value of the company's equity. ${ }^{13}$ The consequence of the IMD in appraisal proceedings is limited in scope, but substantial in scale: in applying a valuation technique (known as "comparable company analysis," or "CCA"14) that estimates subject company value by reference to market trading multiples observed in shares of comparable publicly traded firms, the result must be adjusted upward by adding a premium to offset the "implicit minority discount" asserted to exist in the comparable companies' share prices." In the last several years, the size of this upward adjustment (and the supposed discount that it "corrects") has been routinely fixed, even without supporting expert testimony, at $30 \% .{ }^{16}$

As we show below, ${ }^{17}$ however, not a single piece of financial or empirical scholarship affirms the core premise of the IMD-that public company shares systematically trade at a substantial discount to the net present value of the corporation. To the contrary, the one treatise on

${ }^{11}$ See infra Parts I.B-D (discussing the development of the IMD).

${ }^{12}$ See, e.g., Agranoff v. Miller, 791 A.2d 880, 897 (Del. Ch. 2001) (finding that the use of public company share price data gives rise to "an equity value that includes an inherent minority trading discount, because the method depends on comparisons to market multiples derived from trading information for minority blocks of the comparable companies")

${ }^{13}$ Id.; see also infra Part I.D.

${ }^{14}$ See, e.g., Borruso v. Commc'ns Telesys. Int'l, 753 A.2d 451, 458 (Del. Ch. 1999) (applying the IMD to "the comparable company method of analysis").

${ }^{15}$ Id:; see also infra Part I.D.

${ }^{16}$ See, e.g., Doft \& Co. v. Travelocity.com Inc., No. 19734, 2004 Del. Ch. LEXIS 75, at $* 48$ (May 21, 2004) (applying a $30 \%$ premium to share value based solely upon recent precedent).

${ }^{17}$ See infra Part III. 
which the Delaware courts have repeatedly relied in invoking the IMD has, in its most recent edition, explicitly warned against routinely applying an upward adjustment in order to offset some supposed IMD.

Moreover, the Delaware courts' application of the IMD has rendered their valuation jurisprudence internally inconsistent. Even as they have recently come to insist on adjusting for the putative IMD when using a CCA, the Delaware courts have consistently (and properly) declined to make any such upward adjustment to the results of discounted cash flow (DCF) analysis. That position stems from the courts' correct recognition that DCF analysis can provide the best measure of the value of the enterprise and that the value of the enterprise, after deducting off the value of the debt, measures the value of the firm to its equity holders and thus its going concern value. No adjustments are necessary to the DCF method to offset any implicit minority discount. And indeed, the courts make no such adjustment, even when the DCF analysis relies on market multiples-in substance, a CCA approach-to estimate terminal value. ${ }^{19}$

Fortuitously, in some cases, where allegations of incumbent board wrongdoing are combined with the appraisal case, the IMD may result in the correct answer when it offsets an incumbent controller's wrongful acts. But, as we have argued previously, ${ }^{20}$ that result can be achieved more directly by accepting petitioner's evidence that the respondent's anticipated cash flow projections or other operational performance measures are too low. In short, our core submission is that the Delaware courts, in their valuation of shares (particularly in squeeze-out mergers), should abandon the IMD and rely instead on a more direct approach to addressing concerns about past or future

${ }^{18}$ See infra text accompanying notes 131-132 (citing S.P. PRATT ET AL., VALUING A BUSINESS (4th ed. 2000)).

${ }^{19}$ See, e.g., Gray v. Cytokine Pharmascis., Inc., No. 17451, 2002 WL 853549, at *11 (Del. Ch. Apr. 25, 2002) (conducting a DCF analysis without adjusting the result to account for an IMD), affd, 588 A.2d 255 (Del. 1991); Neal v. Ala. By-Products Corp., No. 8282, 1990 WL 109243, at*7-8 (Del. Ch. Aug. 1, 1990) (same); Cavalier Oil Corp. v. Harnett, No. 7959, 1988 WL 15816, at *29-30 (Del. Ch. 1988) (favoring a DCF analysis that did not include adjustment for an IMD), affd, 564 A.2d 1137 (Del. 1989); cf. In re PNB Holding Co. S'holders Litig., 2006 Del. Ch. LEXIS 158, No. 28-N, at *114 (Aug. 18,2006 ) (noting without citation that "an exit multiple based on minority trading data from ... dubious comparable companies" is "a less favored technique that raises questions about whether it embeds a minority discount"). It appears that Vice Chancellor Strine, the author of the PNB Holding opinion, has recognized the inconsistency we point out.

${ }^{20}$ Hamermesh \& Wachter, supra note 2, at $164-65$ (urging application of a more robust conception of future cash flows as a check on controlling shareholder opportunism). 
abuse by controlling stockholders. The arsenal of corporate finance techniques available to measure going concern value, correctly applied, would award shareholders the appropriate amount.

We reach this conclusion in the following steps. In Part I, we review the fortuitous and haphazard means by which the IMD sprouted up in Delaware valuation law. Part II outlines the finance principles that generally underlie Delaware valuation law, and Part III argues that while such law is generally consistent with those finance principles in both concept and application, the IMD is not. Finally, Part IV suggests how the IMD can easily and fairly be excised from Delaware appraisal law, and how alternative, financially supportable valuation methodology can address controlling stockholder opportunism, as long as the Delaware courts remain true-as we expect they would-to Weinberger's admonition to remain open to evidence from the financial community.

\section{WHENCE IMD?}

As previously noted, the focus of our inquiry is the Delaware courts' recent assertion of the IMD-the proposition that share prices in reasonably active markets systematically and substantially understate the pro rata present value, net of debt, of the firm's free cash flows. In this Part, we examine the background and relatively recent development of that puzzling embrace. ${ }^{21}$ We turn first to a review of the foundational antecedents of Delaware share valuation law. We next review the Delaware courts' initial-and emphatically negativereaction to IMD-type adjustments. Thereafter, we review the critical juncture-less than fifteen years ago-at which the Delaware courts first adopted a share valuation premised upon the IMD adjustment. Finally, we review how that initial acceptance rapidly evolved so that, by 2004 , it had become essentially a rule of law that requires no evidentiary support and, therefore, is unconstrained by contrary evidence of generally accepted financial practice.

21 Richard Booth has made a similar effort to trace the source of the IMD and shares our disagreement with that aspect of Delaware appraisal law. Richard A. Booth, Minority Discounts and Control Premiums in Appraisal Proceedings, 57 BUS. LAW. 127, 148-51 (2001). Carney and Heimendinger also criticize the IMD (noting that "unfortunately, it is the current operative assumption of the Delaware courts") and suggest that the IMD "is offered without any attempt at a theory," but they conclude that responding to the IMD is therefore "impossible and probably not worthwhile." William J. Carney \& Mark Heimendinger, Appraising the Nonexistent: The Delaware Courts' Struggle with Control Premiums, 152 U. PA. L. REV. 845, 863 (2003). 


\section{A. The Doctrinal Soil of the IMD: The Backdrop of Delaware Supreme Court Precedent}

Delaware appraisal law has never been particularly friendly to the idea that stock market prices always accurately represent a proportional share of the value of the enterprise as a going concern. In Chicago Corp. v. Munds, one of the earliest appraisal cases, decided in the depths of the Great Depression, the Court of Chancery vividly outlined its distrust oi financial market prices as exclusive measures of firm value:

When it is said that the appraisal which the market puts upon the value of the stock of an active corporation as evidenced by its daily quotations, is an accurate, fair reflection of its intrinsic value, no more than a moment's reflection is needed to refute it... The experience of recent years is enough to convince the most casual observer that the market in its appraisal of values must have been woefully wrong in its estimates at one time or another within the interval of a space of time so brief that fundamental conditions could not possibly have become so altered as to affect true worth.... The numerous causes that contribute to their nervous leaps from dejected melancholy to exhilarated enthusiasm and then back again from joy to grief, need not be reviewed. ... Even when conditions are normal and no economic forces are at work unduly to exalt or depress the financial hopes of man, market quotations are not safe to accept as unerring expressions of value.

There are two aspects of this superficially hostile view of the abilities of financial markets, however, that suggest compatibility with modern financial theory. First, the court merely rejects the use of share market prices as the exclusize measure of "fair value"; it certainly does not prohibit consideration of market prices in assessing fair value. Second, and more importantly, the court's references to "extreme moods" and "nervous leaps from dejected melancholy to exhilarated enthusiasm" are quite consistent with more recent and modest assertions about the force of the efficient capital markets hypothesis. ${ }^{23}$ In particular, the court's understandably skeptical view of contemporaneous share markets aligns with those who appreciate that prices in reasonably efficient markets suffer from "noise" trading from time to time. On the other hand-and this is a critical point-there is

${ }^{22}$ Chicago Corp. v. Munds, 172 A. 452, 455 (Del. Ch. 1934).

${ }^{23}$ See, e.g., Michael L. Wachter, Takeover Defense when Financial Markets Are (Only) Relatively Efficient, 151 U. PA. L. REV. 787, 798-99 (2003) (discussing studies that indicate that at least temporary mispricing occurs regularly even in well-developed securities markets); Fredrick C. Dunbar \& Dana Heller, Fraud on the Market Meets Behavioral Finance, 31 DEL. J. CORP. L. 455 (2006) (same). 
nothing in Munds that begins to assert that market prices systematically err on the low side relative to firm value or, to use the court's words, "inherent worth." ${ }^{24}$ In short, Munds does not stand for the proposition that publicly traded shares suffer from a persistent "dejected melancholy" or, in modern language, an inherent discount relative to firm value.

When the Delaware Supreme Court first addressed the appraisal statute's concept of "fair value" in Tri-Continental Corp. v. Battye, its holding was much more sympathetic to the efficiency theme in modern finance theory and the importance of share prices in establishing "fair value." ${ }^{25}$ In that case, the court addressed the valuation of shares of a leveraged closed-end investment company (General Shareholdings), in which the Tri-Continental Corporation held a controlling ownership stake. The corporation's net asset value (NAV) significantly exceeded (by around $25 \%$ ) the aggregate market value of its outstanding shares. ${ }^{26}$ In this setting, the Supreme Court correctly articulated the "proportionate interest in a going concern" as "[ $t]$ he basic concept of value under the appraisal statute" that has guided Delaware appraisal law ever since. ${ }^{27}$

With that concept as a guide, one might have expected the Delaware Supreme Court to uphold the lower court's insistence on giving at least partial weight to an estimate of the firm's NAV free of any discount associated with the trading price of the shares. In more recent parlance, the court might have simply explained that the discount was "at the shareholder level," and not "at the corporate level," and might therefore have declined to give any valuation effect to the discount. ${ }^{28}$

${ }^{24}$ Munds, 172 A. at 455.

${ }^{25}$ Tri-Continental Corp. v. Battye, 74 A.2d 71, 75-76 (Del. 1950).

${ }^{26} I d$. at 73. Benjamin Graham, the well-known expert on security analysis, gave a lecture in early 1947 in which he suggested that General Shareholdings (the firm that merged into Tri-Continental the following year) was a bargain in the market, and that the discount created an opportunity for "intelligent speculation." Benjamin Graham, Lecture No. 10, in THE REDISCOVERED BENJAMIN GRAHAM: SElECTED WRITINGS OF A WALL STREET LEGEND 151 (Janet Lowe ed. 1999), available at http://www.wiley.com/ legacy/products/subject/finance/bgraham/benlec10.html. As suggested below, however, the market may have been wiser than Mr. Graham suggested. See infra note 154.

${ }^{27}$ Tri-Continental, 74 A.2d at 72.

${ }^{28}$ Cavalier Oil Corp. v. Harnett, 564 A.2d 1137, 1144 (Del. 1989). Professor John Coates explains at length and with considerable force why Tri-Continental and Cavalier are essentially inconsistent, and why the "shareholder level" and "corporate level" discount parlance is largely meaningless. See John C. Coates IV, "Fair Value" As an Avoidable Rule of Corporate Law: Minority Discounts in Conflict Transactions, 147 U. PA. L. REV. 1251, 1272 (1999) (concluding that "if a 'no-discount' rule is to be taken seriously, then a stronger 
That was not the approach, however, that the Delaware Supreme Court took. To the contrary, it restored the result reached by a courtappointed appraiser, in which estimated NAV was reduced by the observed $25 \%$ market price discount in order to arrive at "fair value." The court explained that failing to give full effect to this discount would be "fail[ing] to face the economic facts"-specifically, the facts that "the only way in which a common stockholder of a going closedend company with leverage can obtain the value of his stock is by the sale of it on the market," and that "whenever he seeks to do so, he, by force of circumstances, must sell at a discount, whenever this is an operating element." ${ }^{30}$

Superficially, then, the analysis in Tri-Continental is friendly to advocates of share market prices as evidence of "fair value." On the other hand, there is a not-so-subtle implication in the case that even in an active market, shares trade at a substantial discount relative to the current value of the firm. ${ }^{31}$ As we will see, this implication-that net asset value could be persistently above market value-may well have contributed to the Delaware courts' eventual receptivity to the IMD concept. Indeed, Tri-Continental $\mathrm{s}$ failure (understandable, to be sure) to appreciate and comment on the unusual nature of closed-end funds may have made the IMD concept easier to accept in the long run.

In hindsight, however, there are several ways in which the court in Tri-Continental could have readily explained the observed discount without implying that share market prices in general are inherently discounted relative to firm value. First, the float of shares of General Shareholdings was small, and the shares were not actively traded. ${ }^{32}$ It

rationale is needed-one that focuses less on the 'level' at which discounts are imposed and more on the working mechanics of the valuation methodologies employed and the sources of discounts, particularly on the existence or absence of control").

${ }^{29}$ Tri-Continental, 74 A.2d at 75 .

Id. at 76 .

${ }^{31}$ The closed-end fund discount has been cited in support of challenges to the Efficient Capital Markets Hypothesis (ECMH) See, e.g., William W. BRATton, CorPoRATE FINANCE: CASES AND MATERIALS 157-58 (5th ed. 2003) (citing J. Bradford De Long et al., Noise Trader Risk in Financial Markets, 98 J. POL. ECON. 703,728 (1990)). For an explanation suggesting that the ECMH is consistent with observed closed-end fund discounts, however, see infra Part II.F.2.

${ }^{32}$ ARTHUR WIESENBERGER, INVESTMENT COMPANIES 152 (1948) ("The 1,602,466 shares outstanding [at December 31, 1947] (held by 2,937 stockholders) are relatively inactive on the New York Curb Exchange. The floating supply is obviously small because Tri-Continental owns $60 \%$....). Just 39,000 shares of General Shareholdings were traded in 1947, the year before the merger that gave rise to the Tri-Continental case. Id. at 153. In contrast, many other closed-end investment companies had much 
is now well established that such thin trading and relative lack of marketability will result in a trading price that may be discounted relative to the value of the firm. ${ }^{38}$ Second, and as we discuss below, the discount to some extent may simply have been a function of the market's perception that the fund's management might extract compensation or fail to manage the fund's assets effectively in the future. ${ }^{34}$ Finally, although we do not associate this with a discount to "fair value," General Shareholdings had a controlling shareholder, ${ }^{35}$ a circumstance that some say results in trading at some discount relative to what the shares would have traded at in the absence of a controlling shareholder. ${ }^{36}$ As we observe below, however, that discount may not be a

more active trading in the same time frame. Id. at 119 (Adams Express Co., 232,000 shares), 129 (American Superpower Corp., 865,000 shares), 131 (Atlas Corp., 187,000 shares), 141 (Chicago Corp., 706,000 shares), 145 (Equity Corp., 413,000 shares), 169 (Pennroad Corp., 439,000 shares), 177 (Tri-Continental Corp., 647,000 shares), 179 (United Corp., 1,980,000 shares). These annual trading volume figures are dwarfed by the levels reflected in today's equity markets, where the daily trading volume of the New York Stock Exchange's most active stocks is typically in the tens of millions of shares. See, e.g., N.Y. TIMES, Most Active, Gainers and Losers, Feb. 9, 2007, at C8 (reporting trading volumes from approximately 18.7 to 88 million shares for each of the twenty-five most active issues). It is perhaps unsurprising, then, that most of the closedend fund shares reflected discounts relative to net asset value that were similar in scale to the discount applicable to General Shareholdings. See WIESENBERGER, supra, at 94 (Pennroad/42\%, Tri-Continental/38\%, Adams Express/35\%, Equity Corp./32\%, Atlas $/ 25 \%$ ). Discussing the closed-end fund discount phenomenon, the source of these statistics reports that such discounts "have shown a characteristic tendency to narrow in rising markets and widen in declining markets," but also notes that "Lehman, a leader in the non-leverage field, sold at small premiums in the final months of 1947 and its closing price was the same as its asset value." Id.

${ }^{33}$ See, e.g., PRATT ET AL., supra note 18, at 392 ("All other things being equal, an ownership interest in a business is worth more if it is readily marketable."); Coates, $s u$ pra note 28, at $1262 \mathrm{n} .35$ (noting the existence of a "marketability discount").

${ }^{34}$ See infra Part II.F.2 (discussing Jonathan Berk \& Richard Stanton, A Rational Model of the Closed-End Fund Discount (Nat'l Bureau of Econ. Research, Working Paper No. 10412, Apr. 2004), available at http://nber.org/papers/w10412.

${ }^{35}$ WIESENBERGER, supra note 32, at 152 ("Tri-Continental owns $60 \%$, Selected Industries $19 \%$ and Central States Electric about 6\%" of General Shareholdings).

${ }^{36}$ See Alexander Khutorsky, Note, Coming in from the Cold: Reforming Shareholders' Appraisal Rights in Freeze-Out Transactions, 1997 Colum. BuS. L. REV. 133, 160 n.169 ("The theoretical existence of a control premium suggests that [the] price of minority shares held in a company controlled by a majority shareholder should be lower than the price of shares held in the same company but with a more dispersed ownership structure."); Coates, supra note 28, at 1278 (“Ceteris paribus, the presence of a control person will reduce the value of publicly held minority shares ...."). Coates wisely cautions, however, that in some instances " $[t]$ he presence of a controlling shareholder may improve managerial monitoring and thus reduce the expropriation value relative to a firm without a controlling shareholder." Id at 1278 n.87. Coates also cites empirical evidence in support of his general assertion. Id. at $1280 \mathrm{n} .93$ (citing Roger C. 
discount relative to "fair value," but may simply reflect agency costs associated with the controlling shareholder that affect the value of the firm and only indirectly affect the value of the shares. ${ }^{37}$

In any event, the next major Delaware Supreme Court decision affecting the discount issue did not come until thirty-five years after TriContinental. In the meantime, in the rubric of the "earnings value" component of the so-called "Delaware block method," the Delaware courts repeatedly used a result derived from comparable company share prices with no adjustment for any discount at all. ${ }^{38}$ It was therefore notable when the Delaware Supreme Court announced in 1985 in Smith v. Van Gorkom - without citation and relying solely on the parties' agreement-that a "publicly-traded stock price is solely a measure of the value of a minority position and, thus, market price represents only the value of a single share." ${ }^{39}$ The thrust of this observation was that the directors could not legitimately rely exclusively on the fact that the merger price exceeded the stock market price as a basis for concluding that the corporation should enter into the merger agreement at issue. ${ }^{40}$

Graham, Jr. \& Craig E. Lefanowicz, Valuation of Companies for the Estate and Gift Tax: Evidence of Minority Interest Discounts, 9 ADVANCES TAX'N 77 (1997)).

${ }^{37}$ See infra Part II.F.2. Of course, as discussed previously, we would agree that "fair value" should not be burdened by agency costs that stem from demonstrable past or anticipated breaches of fiduciary duty.

${ }^{38}$ See, e.g., Associated Imports, Inc. v. ASG Indus., No. 5953, 1984 Del. Ch. LEXIS 483, *44 (June 20, 1984) ("As to an appropriate price/earnings rating, the leading companies in the industry trade in a five to seven range. Given Fourco's modest share of the market and its relatively brief period of success, I find that a multiple of five is appropriate to capitalize annualized earnings."); Francis I. duPont \& Co. v. Universal City Studios, Inc., 312 A.2d 344, 348 (Del. Ch. 1973) (selecting an earnings multiple derived from "the average price earnings ratio of nine motion picture companies"), affd, 334 A.2d 216 (Del. 1975); David J. Greene \& Co. v. Dunhill Int'l, Inc., 249 A.2d 427, 433-34 (Del. Ch. 1968) (referring to price earnings ratios for comparable companies); Felder v. Anderson, Clayton \& Co., 159 A.2d 278, 285 (Del. Ch. 1960) (stating that the multiple was "obtained by averaging the earnings-price ratios of representative stocks for the five year period before the merger").

${ }^{39} 488$ A.2d 858, 876 (Del. 1985). To be fair, the opinion recites that "several of the directors testified that, as a general rule, most chief executives think that the market undervalues their companies' stock." Id. This recitation does not disclose, however, whether the subjectively perceived undervaluation was relative to the present value of the future free cash flows of the firm, or simply what the firm could be sold for as a whole to a third party. It has been suggested in any event that the directors' judgment suffered from "cognitive bias [and therefore was] entitled to little or no credence." Carney \& Heimendinger, supra note 21, at 854 n.48.

${ }^{40}$ Van Gorkom, 488 A.2d at 875 ("[I]n the absence of other sound valuation information, the fact of a premium alone does not provide an adequate basis upon which to assess the fairness of an offering price."). 
We have no literal quarrel with the court's observation or its ensuing legal conclusion. Undoubtedly, in many (if not most) cases, the company can be sold to a third party at a price greater than its share market price because share market transactions do not involve sales of corporate control. Therefore, if a director's obligation is to achieve the highest reasonably available value in a sale of the company, ${ }^{41}$ it was certainly appropriate for the court in Van Gorkom to insist that director approval of a merger not rest entirely on the mere fact that the deal price exceeds the current market price of the company's shares. Unfortunately, however, one could also take Van Gorkom's admonition that the "publicly-traded stock price is solely the value of a minority position" as a sweeping suggestion that all publicly traded shares suffer from a "minority" discount; ${ }^{42}$ as we will soon see, that is exactly what the courts said when they subsequently began to embrace the IMD. Nevertheless, even after Van Gorkom it still could be maintained that no Delaware court had squarely adopted the proposition that share prices in active markets inherently understate firm value.

Four years after Van Gorkom, the Delaware Supreme Court decided Cavalier Oil Corp. v. Harnett, ${ }^{43}$ perhaps the leading Delaware case on the subject of determining "fair value." And like Van Gorkom, Cavalier did not squarely embrace the IMD. To the contrary, its principal relevant holding was simply that the "application of a discount to a minority shareholder is contrary to the requirement that the company be viewed as a 'going concern." "'44 The valuation to which the "minority

${ }^{41}$ See Revlon, Inc. v. MacAndrews \& Forbes Holdings, Inc., 506 A.2d 173, 182 (Del. 1986) (holding that when a company's sale is inevitable, the directors' obligation is to sell to the highest bidder).

${ }^{42}$ Indeed, Van Gorkom's terse remand instruction (directing an award of damages "to the extent that the fair value of Trans Union exceeds $\$ 55$ per share [the market price]," Van Gorkom, 488 A.2d at 893) only reinforces the notion that "fair value" generally exceeds share price. See Lawrence A. Hamermesh, Why I Do Not Teach Van Gorkom, 34 GA. L. REv. 477, 483, 488-89 (2000) (suggesting that this damages formula relying on "fair value" does not accord with Revlon's subsequently expressed requirement of achieving the highest currently available third-party sale value-a value that, unlike "fair value," may include synergies arising from the combination).

43564 A.2d 1137 (Del. 1989).

${ }^{44}$ Id. at 1145 . The court also stated that "to fail to accord to a minority shareholder the full proportionate value of his shares imposes a penalty for lack of control, and unfairly enriches the majority shareholders." Id. (emphasis added). To the extent, therefore, that Cavalier expresses concern about a "penalty for lack of control," it does so only in the limited context where "majority shareholders" are squeezing out a "minority shareholder," and it does not hold that share market prices always penalize a noncontrolling holder. 
discount" was unsuccessfully sought to be applied was a DCF analysis. ${ }^{45}$ As we explain below, any such application of a "minority discount" would be double-counting if the DCF analysis already accurately nets out the firm's agency costs associated with the presence of a controlling shareholder. ${ }^{46}$ We therefore fully concur with the holding in Cavalier that "fair value" determined on a DCF basis should not be burdened by an additional discount that would reflect the fact that shares being appraised are shares of a company with a controlling stockholder. In any event, nothing in Cavalier stands for the proposition that all publicly traded shares are "minority" shares, or that all share prices are therefore subject to a "minority discount."

The first direct attempt to persuade the Delaware courts to accept the IMD emerged in the Court of Chancery in the 1991 case of In re Radiology Associates. ${ }^{47}$ We defer attention to that important case, however, until after we review the one other principal background decision of the Delaware Supreme Court: its 1992 opinion in Rapid-American Corp. v. Harris. ${ }^{48}$ We consider the Rapid opinion to be controversial, to say the least. Its core relevant holding was that in determining the "fair value" of shares of a conglomerate with wholly-owned subsidiaries, "Delaware law compels the inclusion of a control premium" associated with ownership of those subsidiaries. ${ }^{49}$ The trial court's failure to include such a control premium, the court explained, "artificially and unrealistically treated Rapid as a minority shareholder."

It takes little imagination to see that this rationale, carried to its logical conclusion, compels the inclusion of a control premium,

${ }^{45}$ Cavalier Oil Corp. v. Harnett, Nos. 7959, 1988 WL 15816, at *22-23 (Del. Ch. Feb. 2, 1988), aff'd, 564 A.2d 1137 (Del. 1989).

See infra Part II.C.

47611 A.2d 485 (Del. Ch. 1991).

${ }^{48} 603$ A.2d 796 (Del. 1992).

${ }^{49} I d$. at 806 (emphasis omitted); see also M.G. Bancorp., Inc. v. Le Beau, 737 A.2d 513,524 (Del. 1999) ("[I]n valuing a holding company in a statutory appraisal proceeding, pursuant to Section 262, it is appropriate to include a control premium for majority ownership of a subsidiary as an element of the holding company's fair value of the majority-owned subsidiaries."). The trial court in Rapid addressed a valuation in which Rapid's operating subsidiaries were appraised using a comparable company analysis based on share market multiples, and insisted upon the addition of a "control premium" that was derived from observed premiums in acquisitions of companies comparable to Rapid's subsidiaries. Harris v. Rapid-Am. Corp., No. 6462, 1990 Del. Ch. LEXIS 166, at *36 (Oct. 2, 1990), affd in part and rev'd in part, 603 A.2d 796 (Del. 1992) (" $[P]$ etitioners arrived at a control premium of $45 \%$ after looking at control premiums paid for companies during 1980.").

${ }^{50}$ Rapid, 603 A.2d at 806. 
measured by a hypothetical third-party sale value, in all share valuation cases, not just in situations in which the corporation owns its operating assets through controlled subsidiaries. A corporation's control of directly owned assets is at least as great as it would be if those assets were held through controlled subsidiaries. If the going concern itself must be valued on the basis of the hypothetical third-party sale value of its controlled subsidiaries, it is therefore hard to see why it should not also be valued on the basis of the hypothetical third-party sale value of its directly owned operating assets as well. To fail to do so would, to paraphrase Rapid, artificially and unrealistically treat the corporation as the minority owner of its operating assets. Of course, we do not advocate this approach, which we believe is contrary to other Delaware case law, both recent and longstanding.

We are much more inclined to view Rapid as a results-driven ruling, aimed at checking an opportunistic acquisition of control by financier Meshulam Riklis. The merger was the culmination of a scheme by Riklis to acquire $100 \%$ ownership of Rapid, without paying a control premium, through open market purchases and through his subsequent use, as CEO and Chairman, of corporate assets to repurchase shares and thereby increase his ownership to $46.5 \%$ of Rapid's outstanding shares. ${ }^{52}$ If the Delaware courts continue to hold, as we agree they should, that "fair value" is not to be determined by reference to the hypothetical third-party sale value of the firm, they would promote doctrinal integrity by limiting Rapid to its facts and completely rejecting a generalized application of its literal holding. ${ }^{53}$

Of greater present relevance, in any event, is the question of what Rapid does not say about the IMD. In that case, the Delaware Supreme Court insisted that controlled subsidiaries be valued on a basis that included a control premium. ${ }^{54}$ Naturally, then, the court declined to accept, without upward adjustment, a methodology for valuing the subsidiaries that was based on share market prices that did not include a control premium. And given the court's insistence on applying a

${ }^{51}$ See Hamermesh \& Wachter, supra note 2, at 152 n.128 (citing Delaware cases rejecting valuation based on hypothetical third-party sale value).

52 Rapid, 603 A.2d at 799-800.

${ }^{53}$ At least one attempt to limit Rapid to its facts failed, however. See Le Beau v. M.G. Bancorp., Inc., No. 13413, 1998 Del. Ch. LEXIS 9, at *38-39 (Jan. 29, 1998) (rejecting the argument that Rapid's addition of a control premium was limited to situations involving subsidiaries in different lines of business), aff'd in part, 737 A.2d 513 (Del. 1999).

${ }^{54}$ Rapid, 603 A.2d at 806. 
control premium measured by hypothetical third-party sale value, we would agree that share market prices of comparable companies, which do not generally reflect such hypothetical sale value, cannot be used for the purpose demanded by the court. Once again, however, the court in Rapid did not hold that the comparable companies' share market prices were discounted relative to the firms' "going concern value." Rather, on our literal reading of Rapid, the Supreme Court was merely insisting, correctly, that such prices did not reflect the putatively required element of a control premium. Thus, at least through 1992, not a single Delaware case had held that share prices in active markets necessarily understate "going concern value."

\section{B. The Initial Appearance (and Rejection) of the IMD}

The term "implicit minority discount" surfaced for the first time in the Delaware case law in In re Radiology Associates, a 1991 case in which shares of a closely held medical services provider were appraised for purposes of assessing the fairness of a squeeze-out merger. ${ }^{55}$ Having rejected the comparable company/market multiple analysis presented by the plaintiff's expert witness (Anne Danyluk-a name that will return later in this story), the court relied on her valuation based on a DCF analysis. ${ }^{56}$ The plaintiff's expert, however, contended that her DCF result was understated because it "include[d] an implicit minority discount. ${ }^{57}$ More specifically, she claimed that she had derived a discount rate from rates of return demanded on a "minority interest," and that the DCF analysis therefore "fail[ed] to value fully the company as a whole with a premium over market price." 58 Accordingly, she applied a $30 \%$ increment to her DCF result "to represent a fair estimate for premiums over market price."

The Court of Chancery readily rejected the plaintiff's expert's adjustment, agreeing with the defendants' argument that the adjustment was inappropriate "no matter if the plaintiff labels the $30 \%$ as a premium or recompense for a discount." Acknowledging that the DCF

${ }^{55} 611$ A.2d 485, 487-88, 494 (Del. Ch. 1991).

${ }^{56} I d$. at 498 .

${ }^{57}$ Id. at 494

58 Id. Presumably, a "minority" share requires a higher return and, therefore, implies a higher cost of equity and, accordingly, a higher discount rate, thus tending to reduce the valuation derived from the DCF approach.

${ }^{59} I d$. 
approach "may have left out a premium that normally accrues when shareholders sell a company," the court concluded that the "[p]laintiff was not entitled to the proportionate sales value of Radiology.... [and $t$ ] he discounted cash flow analysis ... fully reflects this value without need for an adjustment." ${ }^{61}$

The IMD fared no better in its next outing in the Delaware courts. In Salomon Bros. $v$. Interstate Bakeries Corp., the petitioner's expert added a $15 \%$ upward adjustment to the result of a comparable company market multiple analysis, "to compensate for what he called an 'implicit minority discount." ${ }^{\prime 2}$ The defendant's expert, however, testified that he had "never heard of the expression 'implicit minority discount," and disputed the "premise that market value is inevitably less than intrinsic value." ${ }^{\prime 3}$ According to the Vice Chancellor, the petitioner's expert had failed to demonstrate why his $15 \%$ adjustment "yielded a fair value for the entire company on a going concern basis rather than a premium value, as is often offered in an acquisition." Simply deciding that " $15 \%$ was a reasonable figure" was not, according to the Vice Chancellor, a "level of analysis ... sufficiently reliable to form the basis of a decision on fair value." ${ }^{\prime 5}$

If the Delaware courts' treatment of the IMD had ended here, this Article would have never been written. As we will see momentarily, however, the IMD was introduced into Delaware jurisprudence in separate cases in 1992 and 1995, and in neither case was its existence contested by an expert witness. In the next two Sections we trace the progress of the IMD in those cases and its subsequent evolution into a legal rule.

\section{The IMD Takes Root}

In late 1992, the same Vice Chancellor who had rejected the IMD in the Salomon Bros. case earlier in the year approved a valuation using the IMD. What could possibly have accounted for this change of position? As it turns out, the answer is not revised thinking, but simply for-

61 Id.

${ }^{62}$ No. 10,054, 1992 Del. Ch. LEXIS 100, at*14 (May 1, 1992). Professor Hamermesh represented the petitioner in this litigation, and enjoys the dubious privilege of criticizing the argument he made in that case. The fact that the argument was unsuccessful, at least in that case, is of some comfort.
${ }^{6} I d$. at $* 15$.
${ }^{64}$ Id. at $* 16-17$.
65 Id. at $* 17$. 
tuitous accident. In Hodas v. Spectrum Technology, Inc., Anne Danylukthe same person who had served as the expert for the plaintiff in Radiology-served as the valuation expert for the respondent. ${ }^{66}$ Perhaps to avoid a charge of opportunistic inconsistency, Danyluk, despite acting on the side advocating the lower valuation, added a $30 \%$ premium to the result she derived from analyzing share market multiples of EBDIT, ${ }^{67}$ similar to what she had done (unsuccessfully) in Radiology. Once again, she explained this choice as necessary "to adjust for the fact that the EBDIT multiple reflects a stock price for a single share on a public stock exchange and, thus, includes a minority discount."

In proffering the upward IMD adjustment on behalf of the respondents, however, Danyluk of course met no opposition from the petitioner, and the court did not reject the adjustment sua sponte. To the contrary, the adjustment was incorporated in the final valuation result without comment or evaluation by the Vice Chancellor. ${ }^{69}$ Thus, the IMD was first planted in Delaware valuation doctrine not by adversarial process and judicial evaluation, but by default.

The next sprouting of the IMD in Delaware law occurred three years later, just as it did in Hodas, in a case where none of the valuation experts contested the existence of an IMD in public market share prices. In Kleinwort Benson Ltd. v. Silgan Corp., the court heard from three valuation experts: one presented by the petitioners, one presented by the respondent, and a neutral expert retained by the court. $^{70}$ The petitioner's expert added an $86 \%$ premium to the result he reached using a comparable company share market multiple analysis. ${ }^{71}$ At trial, the respondent's expert testified that "'the preponderance of opinion is that there is some minority interest that's implicit

${ }^{606}$ No. 11,265, 1992 Del. Ch. LEXIS 252, at *4 (Dec. 7, 1992). Once again, it must be noted that Professor Hamermesh acted as counsel for the petitioner in this case. In this case, the petitioner did not so much advocate the IMD as omit, in his self-interest, to oppose the respondent's expert's use of it.

${ }_{67}$ Earnings before depreciation, interest, and taxes.

68 Id. at *5. On the other hand, Danyluk also applied a $40 \%$ discount for lack of marketability, a discount that the Vice Chancellor rejected as inconsistent with Delaware law. $I d$. at $* 6, * 14-15$.

Id. at $* 10$.

${ }^{70}$ No. 1107,1995 Del. Ch. LEXIS 75 , at $* 2-3$ (June 15, 1995). The use of a courtappointed expert, while a well-known possibility, has been an unusual step in Delaware appraisal proceedings, suggesting that the courts have not found it to be of substantial assistance. See Cede \& Co. v. Technicolor, Inc., 758 A.2d 485, 496-97 (Del. 2000) (rejecting trial court appointment of valuation expert to conduct "quasi-judicial functions").

"Kleinwort, 1995 Del. Ch. LEXIS 75, at*6. 
in a publicly traded company's price.",72 The court-appointed expert also asserted that some premium was "necessary to remove the minority discount inherent in publicly traded stock...." ${ }^{\text {s9 }}$ Thus, while respondent's counsel had instructed its expert that application of a premium to compensate for IMD was contrary to Delaware law, ${ }^{74}$ no expert testified unequivocally against the existence of an IMD. The court therefore had no choice, " $[u]$ pon the record presented," but to "conclude that both experts should have adjusted market value to compensate for an inherent minority discount." ${ }^{, 75}$ Acknowledging that this conclusion squarely contradicted the 1992 ruling in Salomon Bros., the Chancellor simply chalked up the difference to the fact that the records in the two cases were different, and that the record in the case at hand-including undisputed testimony that the IMD existedcompelled a finding "that the market price for publicly traded stock includes a minority discount.,"

That left the Chancellor to determine the magnitude of the adjustment required by the IMD. Petitioner's expert had pegged it at $86 \%$, an amount derived more or less from observed control premiums paid in recent mergers. ${ }^{77}$ The Chancellor rejected that number, however, as impermissibly including "value arising from synergies or new management plans," and ruled that the adjustment based on control premium data should have been reduced "so that it reflected just the minority discount." The respondent's expert, despite having been instructed by the respondent that the IMD was improper as a matter of law, allowed at trial that "a reasonable estimate of the minority discount is around 10-15\%." ${ }^{79}$ And the court-appointed expert concluded that "setting an exact figure for the minority discount comes down to an arbitrary determination." Rather than take the approach adopted in Salomon Bros., however, where the Vice Chancellor found a conclusory estimate to be insufficiently reliable as a basis

72 Id. at $* 8$.

73 Id. at *11-12.

74 Id. at $* 12$.

75 Id. at $* 8$.

${ }^{76}$ Id. at $* 8-9$.

77 Id. at $* 10-11$

78 Id. at $* 11$.

${ }^{79}$ Id. at *12. The opinion does not recite any analysis or empirical support underlying this estimate.

${ }^{80}$ Id. 
for an upward IMD adjustment, ${ }^{81}$ the Chancellor in Kleinwort concluded that choosing a zero adjustment was "more arbitrary than endeavoring to find its true value," $"$ and simply chose the midpoint $(12.5 \%)$ of the range proffered in conclusory fashion by the respondent's expert. $^{83}$

Therefore, as matters stood after Kleinwort the IMD had not yet taken root as a legally mandated principle; it was simply a matter to be determined on the strength of the expert testimony in the case. It was at least theoretically possible for a respondent-engaged valuation expert to assert that the IMD did not truly exist as a general proposition, and for a court to accept that testimony if it was better substantiated than any contrary testimony from the petitioner. For better or worse, however, the Delaware courts' next encounter with the IMD occurred in a case in which the respondents' expert had coauthored a book stating that the "comparative publicly traded company valuation technique produce[s] a minority discounted valuation" that the courts viewed as supporting the existence of an IMD. ${ }^{85}$

\section{The IMD Goes from Permissible to Mandatory}

In Le Beau v. M.G. Bancorporation, Inc., the respondents' expert analyzed the value of the company's two subsidiaries on the basis of comparable company share market multiples. ${ }^{86}$ The petitioners attacked that analysis as improper because "it include[d] a built-in minority discount." $^{87}$ The Vice Chancellor concurred, because "[ $\left.t\right]$ he valuation literature, including a treatise coauthored by [the respondents' expert] himself, supports that position, and Respondents have introduced no evidence to the contrary." On appeal, the Delaware Supreme Court

${ }^{81}$ Salomon Bros. v. Interstate Bakeries Corp., No. 10,054, 1992 Del. Ch. LEXIS 100 , at $* 17$ (May 1, 1992).

${ }^{82}$ Kleinwort Benson Ltd. v. Silgan Corp., No. 1107, 1995 Del. Ch. LEXIS 75, at *12 (June 15, 1995).

${ }^{83} \mathrm{Id}$.

${ }^{84}$ M.G. Bancorp., Inc. v. LeBeau, 737 A.2d 513, 522 n.26 (Del. 1999) (referring to S.P. PRATT ET AL., VALUING A BUSINESS 194-95, 210 (3d ed. 1996)).

${ }^{85}$ We explain below that this reading of Pratt is flawed, and that the so-called "minority" valuation approach described by Pratt et al. includes the kind of DCF analysis that the Delaware courts routinely and appropriately accept as a basis for determining "fair value." See infra Part III.B.

${ }^{86}$ No. 13414, 1998 Del. Ch. LEXIS 9, at *11 (Jan. 29, 1998), affd, 737 A.2d 513 (Del. 1999).

${ }^{87}$ Id. at $* 25$.

${ }^{88}$ Id. The only pieces of "valuation literature" cited by the court were the Pratt 
affirmed this ruling, finding that the Vice Chancellor's conclusions were "fully supported by the record evidence that was before the Court of Chancery and [by] the prior holdings of this Court construing Section 262." ${ }^{89}$ In short, in a case where one expert declined to use an IMD adjustment to a comparable company share market multiple analysis, his view was rejected because of outside "literature" (including in particular a book that he had coauthored) and because of "prior holdings" of the Delaware Supreme Court. Thus, the courts' acceptance of the IMD was no longer purely an evaluation of expert testimony in the record; now, just seven years since the IMD was rejected in the Delaware courts, outside "literature" and prior judicial acceptance took on the imprimatur of authority for use of the IMD.

After Le Beau, the IMD's momentum accelerated, with several Delaware valuation decisions routinely finding the existence of an IMD and applying an upward adjustment to a comparable company share market multiple valuation approach. ${ }^{90}$ This occurred when respondents failed to offer contrary expert testimony, or to contest the existence of an IMD at all. ${ }^{91}$ In one of those cases, Agranoff $v$. Miller,

treatise and Z. CHRISTOPHER MERCER, VALUING FINANCIAL INSTITUTIONS 198-200, $207-$ 41 (1992). As explained below, neither of these authorities, properly understood, asserts the existence of an IMD. See infra Part III.B.

${ }^{89}$ M.G. Bancorp., 737 A.2d at 523. Citing its earlier opinion in Rapid, the Supreme Court similarly upheld the Vice Chancellor's acceptance of an analysis of the subsidiaries' value that was based on premiums paid in acquisitions of comparable companies. Id. at 525 .

${ }^{90}$ See, e.g., Borruso v. Commc'ns Telesys. Int'l, 753 A.2d 451, 458 (Del. Ch. 1999) (" $[\mathrm{T}]$ he comparable company method of analysis produces an equity valuation that inherently reflects a minority discount, as the data used for purposes of comparison is all derived from minority trading values of the comparable companies. Because that value is not fully reflective of the intrinsic worth of the corporation on a going concern basis, this court has applied an explicit control premium in calculating the fair value of the equity in an appraisal proceeding. It would seem to me to be particularly appropriate to do so where, as is true here, the comparable company method is the only method available to me to value the shares in question." (citation omitted)); Bomarko, Inc. v. Int'l Telecharge, Inc., 794 A.2d 1161, 1185 (Del. Ch. 1999) (accepting a comparable company analysis to which a $30 \%$ premium had been applied in order "to account for the minority discount inherent in the comparable companies analysis"); Agranoff v. Miller, 791 A.2d 880, 892-93, 897 (Del. Ch. 2001) ("The comparable companies analysis generates an equity value that includes an inherent minority trading discount, because the method depends on comparisons to market multiples derived from trading information for minority blocks of the comparable companies.").

${ }^{91}$ In Borruso, the court recites that "[ $t$ ] here is no dispute between [the parties] that the comparable company method produces a minority valuation of the shares subject to appraisal, as has been recognized in decisions of this court." $753 \mathrm{~A} .2 \mathrm{~d}$ at 457. In Bomarko, the defendants did "not dispute that the value derived by comparable companies method of analysis reflects an imbedded minority discount." $794 \mathrm{~A} .2 \mathrm{~d}$ at 1186. 
the Vice Chancellor described the IMD adjustment-then less than ten years old-as "a rigid, formulaic correction," and declined to apply it in his preferred valuation approach under the unusual circumstances of the case. ${ }^{92}$ Nevertheless, the Vice Chancellor indicated that had he been bound to apply the "fair value" standard developed in statutory appraisal proceedings, the result would have given effect to an upward IMD adjustment. ${ }^{93}$

By 2004, in any event, it became clear that Delaware's IMD doctrine no longer depended upon expert testimony, and that it had become established as an element of valuation law. Doft $\mathcal{E}$ Co. v. Travelocity.com Inc. ${ }^{94}$ represents the culmination of this doctrinal development. The experts in that case both had formidable credentials. Both experts developed a comparable company share market multiple valuation. ${ }^{96}$ Neither expert, however, urged that the result should be augmented to eliminate a putative IMD; as the Vice Chancellor explained, " $[t]$ he parties are silent on the proper application of a control premium." ${ }^{97}$ At this point, however, the absence of expert testimony no longer mattered; according to the court, "Delaware law recognizes that there is an inherent minority trading discount in a comparable company analysis ... [and] the court, in appraising the fair value of the equity, 'must correct this minority trading discount by adding back a premium designed to correct it." ${ }^{98}$ The expert wit-

In Agranoff, the expert witness for the party arguing for a low "fair value" appears to have challenged only the size of the IMD adjustment, and not the proposition that such an adjustment was appropriate. $791 \mathrm{~A} .2 \mathrm{~d}$ at 899-900.

92 A.2d at 893 .

${ }^{93}$ That IMD adjustment was calculated by means of what the Vice Chancellor candidly described as "a necessarily rough approach that simply involves shaving some percentage off the top of the available information about control premiums paid." Id. at 899 .

${ }^{94}$ No. 19734, 2004 Del. Ch. LEXIS 75 (May 21, 2004).

${ }_{95}$ The petitioners' expert was William $H$. Purcell, an investment banker with over thirty-five years of experience in significant mergers and acquisitions. Id. at *14. The respondent presented the testimony of Professor Paul A. Gompers of the Harvard Business School. Id. at *15. Salomon Smith Barney, Inc., which had counseled the special board committee involved in the transaction, was also a source of valuation expertise. Id. at $* 12$.

${ }^{96}$ Id. at $* 32$.

${ }^{97}$ Id. at $* 46$.

${ }^{98}$ Id. (citing Agranoff v. Miller, 791 A.2d 880, 892 (Del. Ch. 2001)). In 2003, however, the same Vice Chancellor relied in part on a comparable companies market multiple analysis but declined to impose an upward IMD adjustment, noting that " $[t]$ he petitioner's expert made no such adjustment because he assumed it would be roughly offset by a marketability discount related to [the firm's] status as a privately held com- 
nesses offered essentially no support for this view. To his considerable credit, the petitioners' expert testified simply that "if the court is to accept the theory that 'some minority discount from going concern value' is appropriate in a comparable company analysis, then the correct valuation would be above his stated value." Thus, left with no expert testimony about the magnitude of the now legally required adjustment, the Vice Chancellor set the IMD adjustment at $30 \%$, relying exclusively on "recent appraisal cases that correct the valuation for a minority discount by adding back a premium."100

So matters stood as of 2004. Both in existence and scaie, the IMD had been established as a matter of Delaware law, and it has continued to be used to support an upward adjustment to valuations derived from share market multiples observed in comparable publicly traded companies. ${ }^{101}$ At the same time, the Delaware courts continue to resist (appropriately, we believe) the application of a similar upward adjustment to discounted cash flow valuations. ${ }^{102}$ Indeed-and in a striking in-

pany." Taylor v. Am. Specialty Retailing Group, Inc., No. 19239, 2003 Del. Ch. LEXIS 75 , at $* 23$ n.24 (July 25, 2003).

${ }^{99}$ Travelocity.com, 2004 Del. Ch. LEXIS 75, at *46.

${ }^{100}$ Id. at *46-47 (citing Agranoff, 791 A.2d at 887; Bomarko v. Int'l Telecharge, Inc., 794 A.2d 1161, 1186 n.11 (Del. Ch. 1999), affd, 766 A.2d 437 (Del. 2000); Borruso v. Commc'ns Telesys. Int'l, 753 A.2d 451, 459 (Del. Ch. 1999)).

${ }^{101}$ See, e.g., Andaloro v. PFPC Worldwide, Inc., Nos. 20336, 2005 Del. Ch. LEXIS 125 , at $* 65, * 70-71$ (Aug. 19, 2005) (applying a 30\% upward adjustment in order " $[t]$ o honor the Supreme Court's teaching that plaintiffs should receive their pro rata share of the entity as a going concern, this court's decisions adjust minority trading multiples to account for the implied discount, in order to accurately arrive at a fair value of the entire entity"); Dobler v. Montgomery Cellular Holding Co., No. 19211, 2004 Del. Ch. LEXIS 139, at *65-66 (Oct. 4, 2004) (accepting a comparable company valuation to which a "control premium" had been added), aff'd in part, rev'd in part on other grounds, 880 A.2d 206 (Del. 2005); Lane v. Cancer Treatment Ctrs. of Am., Inc., No. 12207, 2004 Del. Ch. LEXIS 108 at *129-30 (July 30, 2004) ("Comparable company analysis ... suffers from an inherent minority discount... [and] a "premium must be added to adjust for the minority discount."). Interestingly, in Andaloro the court thought it would be "appropriate" to reduce the $38 \%$ adjustment proffered by defendants' expert witness to $30 \%$ because the $38 \%$ figure "did not seek to exclude any portion of the average premia ... to account for the sharing of synergies by the buyer with the seller." 2005 Del. Ch. LEXIS 125, at *69, *70 n.74. Also, the Vice Chancellor did acknowledge that " $[t]$ here is some academic dispute about whether all companies' shares trade at a discounted level." Id. at *65 n.69.

${ }^{102}$ Dobler, 2004 Del. Ch. LEXIS 139, at *72 ("A DCF is a final valuation that does not need any additional correction, such as a control premium."); Lane, 2004 Del. Ch. LEXIS 108, at *117-18 \& nn.159-60 (citing In re Radiology Assocs. Inc. Litig., 611 A.2d 485, 491 (Del. Ch. 1991) and Shannon PRATT, Business VAluation DiscounTs AND PREMIUMS 30 (2001)) ("The streams of income here do not require any adjustment for an impermissible minority discount."). According to Pratt, "There is little or no difference in the rate of return that most investors require for investing in a public, freely 
stance of internal inconsistency-the Delaware courts have accepted DCF valuations based on terminal values estimated using an exit multiple approach, without making any IMD-type upward adjustment to the terminal value. ${ }^{103}$ An IMD adjustment to DCF valuation analysis remains today, then, where such an adjustment to comparable company market multiple analysis stood in 1992 . While the courts remain open to the "intellectually interesting argument in support of the proposition that the DCF analysis necessarily introduces something of a minority discount," they have not yet accepted it as a matter of law and continue to reject it in the absence of persuasive evidence. ${ }^{104}$

\section{The FinanCE BEHIND Delaware APPRAisal LAW}

Having shown how the IMD was planted and then nurtured in case law, it is time to turn back to examining whether finance theory and empirical evidence support the IMD. We argue that they do not. Before reviewing how the Delaware courts might have come to a contrary view, however, we need to examine five core finance concepts: going concern value; third-party sale value and synergies; the incidence of agency costs; the nature of the benefits of control; and market discounts. We discuss each of these in turn.

\section{A. The Value of the Firm}

The first concept is the value of the firm as that term is understood in corporate finance. In valuing a company it is generally accepted that discounting the firm's free cash flows provides the best measure of

tradable minority interest versus a controlling interest." PRATT, supra, at 30.

${ }^{109}$ E.g., In $r$ U.S. Cellular Operating Co., No. 18696, 2005 Del. Ch. LEXIS 1, at *67 (Jan. 6, 2005) (selecting "a terminal value multiple of 10 times EBITDA"); Gray v. Cytokine Pharmascis., Inc., No. 17451, 2002 WL 853549, at *11 (Del. Ch. Apr. 25, 2002) (“[A] revenue multiple of 4.0x should be applied to PSI's projected revenues in 2008 to determine most accurately the Company's terminal value."); Neal v. Ala. ByProducts Corp., No. 8282, 1990 WL 109243, at *7 (Del. Ch. Aug. 1, 1990) (setting the terminal value to be "equal to a price earnings multiple of 14 times annual earnings ... plus a premium for $100 \%$ ownership"), aff d, 588 A.2d 255 (Del. 1991); Cavalier Oil Co. v. Harnett, 1988 WL. 15816, at *21 (Del. Ch. 1988) (multiplying the company's average yearly earnings plus the actual earnings in the year before merger by 12 to determine the terminal value), aff $d, 564$ A.2d 1137 (Del. 1988). In fairness, it should be pointed out that Vice Chancellor Strine anticipated this inconsistency. See In re PNB Holding Co. S'holders Litig., No. 28-N, 2006 Del. Ch. LEXIS 158, at *114-15 (Aug. 18, 2006) (characterizing the exit multiple approach as "a less favored technique that raises questions about whether it embeds a minority discount").

${ }^{104}$ Lane, 2004 Del. Ch. LEXIS 108, at*118 n.160. 
value. More specifically, for a firm with both debt and equity, the accumulated future cash flows to all claim holders in the firm are discounted using the weighted average cost of capital. ${ }^{105}$ Using the cost of capital approach, the enterprise value of the firm is thus the following:

$$
V_{F}=\frac{F C F F_{1}}{(1+W A C C)}+\frac{F C F F_{2}}{(1+W A C C)^{2}}+\cdots+\frac{F C F F_{H}}{(1+W A C C)^{H}},
$$

where $V_{F}$ is the value of the firm financed using both debt and equity, $F C F F_{t}$ is the free cash flow in year $t, W A C C$ is the weighted average cost of capital, and $H$ is equal to infinity. ${ }^{106}$ In the appraisal setting, the court's function is to value the equity of the firm. This can be done by calculating $V_{F}$ and subtracting the value of the debt.

Since appraisal is about valuing equity, and since the focus of this Article is to analyze the IMD, the exposition is simplified by assuming that the above steps have been accomplished, and that we are then left with the value of the equity $\left(V_{E}\right)$. An even more important simplifying assumption is to assume hereafter that the firm being appraised is financed entirely with equity. In this case $V_{F}=V_{E}{ }^{107}$

For the all-equity firm, its value is the discounted value of the free cash flows that the corporation's assets will produce over the indefinite life of the corporation. Both Delaware appraisal law and finance textbooks typically divide the calculation of $V_{E}$ into three steps. ${ }^{108}$ The first step is to determine the annual free cash flows (FCFs) over a horizon period $(H)$, for which forecasts are available. The second is to determine a terminal value $\left(P_{H}\right)$ representing the value of the free cash flows beginning with the first year after which annual forecasts are available. Finally, since future FCFs and the terminal value have to be discounted to their present value, the court must determine the company's cost of equity capital $\left(r_{E}\right)$ :

$$
V_{E}=\frac{F C F_{1}}{\left(1+r_{E}\right)}+\frac{F C F_{2}}{\left(1+r_{E}\right)^{2}}+\cdots+\frac{F C F_{H}}{\left(1+r_{E}\right)^{H}}+\frac{P_{H}}{\left(1+r_{E}\right)^{H}} .
$$

${ }^{105}$ ASWATH DAMODARAN, DaMODARAN ON VALUATION 193 (2d ed. 2006).

${ }^{100}$ Id. at 31.

${ }^{107}$ There are many interesting problems involved in the determination of the cost of capital, but these are beyond the scope of this Article.

${ }^{108}$ See, e.g., Henke v. Trilithic Inc., No. 13155, 2005 Del. Ch. LEXIS 170, at *20 (Oct. 28, 2005); ONTI, Inc. v. Integra Bank, 751 A.2d 904, 917 (Del. Ch. 1999); RICHARD A. BREALEY ET AL., PRINCIPLES OF CORPORATE FINANCE 508-12 (8th ed. 2006). 
The starting point for FCF estimates is incumbent management's estimates for the forecast period. ${ }^{109}$ In the adversarial setting of an appraisal, these forecasts will be challenged by the petitioners. Since the petitioners believe that the fair value of the corporation is higher than the price offered by the respondent, they will offer their own evidence that FCFs within the forecast period are higher, the terminal value is higher, and/or the discount rate is lower. ${ }^{110}$

In most cases, a great deal of the value of the company is captured by the terminal value. The terminal value is calculated using one of two approaches. First, using the Gordon growth model, Equation (2) can be rewritten in the following form: ${ }^{11}$

$$
V_{E}=\frac{F C F_{1}}{\left(1+r_{E}\right)}+\frac{F C F_{2}}{\left(1+r_{E}\right)^{2}}+\cdots+\frac{F C F_{H}}{\left(1+r_{E}\right)^{H}}+\frac{F C F_{H+1}}{\left(r_{E}-g\right)} \times \frac{1}{\left(1+r_{E}\right)^{H}},
$$

where $g$ is an estimate of the firm's future growth rate, and $\frac{F C F_{H+1}}{\left(r_{E}-g\right)}$ is $P_{H}$, the nondiscounted terminal value.

The second method used by the appraisal court and by finance experts in calculating the terminal value is the comparable compan method. This is implemented by recognizing that $P_{H}$ from Equation (2) can also be estimated using financial market multiples, or "exit multiples," ${ }^{112}$ where $P_{H}$ is represented by

$$
P_{H}=F C F_{H} \times \text { market multiple for } F C F \text {. }
$$

Therefore, we have:

$$
V_{E}=\frac{F C F_{1}}{\left(1+r_{E}\right)}+\frac{F C F_{2}}{\left(1+r_{E}\right)^{2}}+\cdots+\frac{F C F_{H}}{\left(1+r_{E}\right)^{H}}+\frac{F C F_{H+1}}{\left(1+r_{E}\right)^{H}} \times \text { marketmultiple for } F C F \text {. }
$$

The market multiple is the average multiple that the financial markets assign to the comparable companies. For example, suppose

${ }^{109}$ See, e.g., Cede \& Co. v. Technicolor Inc., No. 7129, 2003 Del. Ch. LEXIS 146, at *25 (Dec. 31, 2003) (quoting Agranoff v. Miller, 791 A.2d 880, 892 (Del. Ch. 2001)), aff d in part, rev'd in part on other grounds, 875 A.2d 602 (Del. 2005).

110 Sometimes the respondents in valuation proceedings, seeking a lower result, challenge the application of what they consider to be inapplicable or unduly optimistic forecasts. E.g., Prescott Group Small Cap, L.P. v. Coleman Co., No. 17802, 2004 Del. Ch. LEXIS 131, at *22-39 (Sept. 8, 2004).

II! DAMODARAN, supra note 105, at 158.

112 The Delaware courts regularly describe this method of estimating terminal value as the "exit multiple" approach. E.g., Gholl v. eMachines, Inc., No. 19444, 2004 Del. Ch. LEXIS 171, at *50 (Nov. 24, 2004). 
comparable companies trade at an FCF multiple of 8 . A company that has an FCF of, say, $\$ 5$ a share will be assigned a terminal value of $\$ 40$ a share. Numerous market multiples can be used and are used instead of an FCF multiple. Other market multiples include the ratio of stock price to earnings ( $\mathrm{P} / \mathrm{E}$ ratio), stock price to book value, and stock price to EBDIT. The choice of the multiple depends on what data are most reliable.

Equations (3) and (5) are mathematically equivalent, and the courts refer to the valuation technique using either of these equations as the income approach, or DCF approach. ${ }^{113}$ We agree, but we also note that Equation (5) uses a comparable company method in determining the terminal value. The choice between the two methods to estimate terminal value depends on data reliability and availability. When data are available for both methods, Equation (3) is the preferred method since it depends entirely on company-specific data. ${ }^{114}$ In appraisal cases, however, in which relevant company-specific data may be either unavailable or unverifiable, the virtue of using Equation (5) is that its use of comparable company analysis to estimate terminal value bypasses the need to have an estimate for the company-specific future growth rate $g .{ }^{115}$ The downside of using the comparable company analysis, on the other hand, is that its accuracy depends on the availability of comparable companies' data.

The Delaware courts typically refer to the appraisal as relying on a comparable company analysis only when comparable company data are used without a near-term forecast period. ${ }^{116}$ This approach looks

${ }^{113}$ See, e.g., id. at $* 26, * 50$ n.87 (describing a DCF analysis and noting the use in such analysis of both approaches to estimating terminal value). The expert may estimate $g$ and $r$ in Equation (2) using average rates for comparable companies, either to justify her estimate of $V_{\varepsilon}$ or to provide a range.

${ }^{114}$ Damodaran states that the relative valuation method, which relies on a comparable company analysis, is inferior to the use of what we call the pure DCF method because of the difficulties in determining comparables. DAMODARAN, supra note 105, at 231.

${ }^{115}$ Future growth is notoriously difficult to forecast. In particular, to forecast $g$, the expert needs to estimate the company's future marginal return on equity, which can be highly problematic.

${ }^{116}$ See, e.g., Andaloro v. PFPC Worldwide, No. 20336, 2005 Del. Ch. LEXIS 125, at *64 (Aug. 19, 2005) ("The comparable companies method of valuing the company's equity involves several steps including: finding comparable, publicly-traded companies that have reviewable financial information; calculating the ratio between the trading price of the stocks of each of those companies and some recognized measure reflecting their income such as revenue, EBIT or EBITDA; correcting these derived ratios to account for differences, such as capital structure, between the public companies and the target company being valued; and finally applying the average multiple to the relevant income measurement of the target company, here PFPC. The methodology rests 
just like the approach to estimating terminal value in the DCF method (see Equation (4)), except that in the expression $P_{H}, H=1$. In other words, if FCF is the operative performance criterion to which comparable company trading multiples will be applied, the near-term is only one year and the terminal value (now the entire measure of value) is a multiple of a one-year estimate of FCF. In this case, the only datum provided by the company is the FCF for the next year. Therefore,

$$
V_{E}=F C F_{1} \times \text { market multiple for FCF. }
$$

Perhaps because of the simplicity of this formula, one might conclude that this comparable company approach (Equation (6)) to estimating value is conceptually distinct from Equation (5). But this is not the case: they differ only with respect to the value of $H$. Equation (6) is a pure comparable company analysis with no variation in FCF in future years, while Equation (3) is a mixed version.

It is also the case that the pure comparable company approach of Equation (6) is very much a DCF-type methodology. One way to show this is to make the point again that Equations (6) and (5) differ only with respect to the value of $H$; and therefore, since Equations (5) and (3) are conceptually the same, Equation (6) is also a DCF-type methodology.

Alternatively, we point out that Equation (6) (the pure comparable company approach) can be restated in a way that is visually and conceptually identical to the DCF approach:

$$
V_{E}=\frac{F C F_{1}}{\left(1+r_{E}\right)}+\frac{F C F_{2}}{\left(1+r_{E}\right)^{2}}+\cdots+\frac{F C F_{H}}{\left(1+r_{E}\right)^{H}} .
$$

In this equation, $H$ is infinity, and the various FCFs are the same in each and every future year. Although Equations (6) and (7) may look very different, we note that the market multiple of Equation (6) captures the value of a perpetuity in the annual amount of FCF, discounted at the rate, $r_{E}$.

Thus, the comparable company technique is just as much a DCF form of analysis as what the courts usually describe as DCF analysis. The significant differences are, simply, that (a) anticipated FCFs are

on the reasonable assumption that, after making the appropriate adjustments, the subject company would tend to have its free cash flows valued at the same multiples as its industry peers."); Agranoff v. Miller, 791 A.2d 880, 892 (Del. Ch. 2001); Bomarko, Inc. v. Int'l Telecharge, Inc., 794 A.2d 1161, 1186 n.11 (Del. Ch. 1999) (accepting a comparable companies analysis even when the comparable companies are different in size and scope provided that other chosen multiples will correct for the differences). 
the same for all future years, and (b) unlike the Gordon growth model approach reflected in Equation (3), but like the exit multiple variation reflected in Equation (5), the comparable company approach also depends upon the use (explicit or implicit) of a discount rate estimated from the discount rate of comparable companies. ${ }^{117}$

We recognize and share a preference, however, for the use of whatever good, company-specific forecast data are available. Consequently, the terminal value should be pushed as far back into the future as forecasting ability reliably permits. For example, when company-specific forecasts are available for 10 years, then the market multiple is applied to the FCF in year 11. The more years for which reliable, company-specific forecast data are available, the further out the horizon value can be pushed. At some point the company's future forecasts become unacceptable because of diminishing reliability. At that point, and in the absence of a reliable estimate of the subject company's future growth rate, the CCA should be inserted. That can be where $H=1, H=10$, or where $H$ equals any other value.

Invariably, in either appraisal cases or in standard financial practice, several methods are used either to confirm the results from Equation (2) or to provide a range for the valuation. As explained earlier, however, DCF and CCA are not conceptually distinct methods for calculating the company's going concern value. Both are rooted in the observation that the value of the company depends on its discounted free cash flows. Equations (3), (5), and (6) are thus merely different algorithms for calculating the value of a company's future discounted free cash flows.

Since all of the different equations are simple transformations of each other, the choice of methods is driven by what reliable data are available. All of these methods should, or could, if the correct data were available, lead to the same result. In finance textbooks, all of these methods are taught as being alternative algorithms that are consistent with determining the $V_{E}$ of a firm by discounting its future free cash flows. ${ }^{118}$

${ }^{117}$ When comparable companies analysis is used in appraisal proceedings, the discount rate is effectively selected through the choice of a market multiple; the discount rate implied in these applications of the comparable companies analysis is the reciprocal of the selected market multiple. PRATT ET AL,, supra note 18, at 244 ("Multiples of economic income variables (price/earnings multiples, price/cash flow multiples, and so on) are the reciprocals of the capitalization rates applicable to those variables.").

${ }^{118}$ Brealey et. al. discuss the use of multiples as a good method for checking the validity of what we call the pure DCF approach in calculating the horizon value of the 
There is one other lesson to be learned from finance textbooks, and this may be the most crucial lesson of all. In finance textbooks, the above formulas for calculating the value of the firm are taught in the context of how to value the common stock of the firm. That is, the value of the stock is calculated to be the pro rata net present value of all future free cash flows. There are no adjustments. No discounts are assumed, and no premiums are added. The textbook equation for the value of a stock is essentially the same as Equation (3), which measures the value of the firm. To move from $V_{E}$ to the value of the stock, one need only divide $V_{E}$ by the number of shares. ${ }^{119}$ We return to this point on several occasions below, because if the finance textbooks are correct, there cannot be a persistent and continuously occurring IMD in all traded stocks.

\section{B. Third-Party Sale Value and Synergies}

The value of the firm is not its third-party sale value $\left(V_{3 P S}\right) .{ }^{120}$ In an arm's-length transaction, an acquirer will pay a premium to $V_{E}$ in purchasing the firm. The premium largely reflects synergies arising from the merger, but it can also reflect benefits of control. ${ }^{21}$ Assuming that

firm. BREALEY ET AL., supra note 108, at 511. Damodaran refers to the use of multiples as "relative valuation." See DAMODARAN, supra note 105, at 231 "In relative valuation, we value assets based on how similar assets are priced. We begin ... by noting that most valuations in practice are relative valuation.").

${ }^{119}$ See BREALEY ET AL., supra note 108, at 61-65. Ross, Westerfield, and Jaffe define the value of common stocks in an identical fashion. STEPHEN A. ROSS ET AL., CORPORATE FINANCE 109 (6th ed. 2002). These textbooks define the value of a stock as the discounted value of dividends and elsewhere define the value of the firm as the discounted value of future FCFs. As Damodaran points out, these values measure the same thing: cash flows to equity holders. DAMODARAN, supra note 105, at 175. Damodaran discusses scenarios in which dividend discounting and free cash flow discounting could lead to different valuations, namely when free cash flows are neither paid as dividends nor reinvested in the firm. Id at 188 . However, these scenarios may represent a form of agency cost, which, as discussed in detail below, is appropriately reflected in (a reduced) going concern value. See infra Part II.C. To the extent that these scenarios involve breaches of fiduciary duty, it can be argued that they should be addressed by an offsetting upward adjustment in determining fair value. See infra Part IV. In any event, Damodaran notes that his analysis switches freely between per-share and aggregate valuations. See DAMODARAN, supra note 105, at 191 (discussing the differences between these two forms of valuation). He makes no mention of a need to include a discount when moving from a value of the firm as a whole to the value of individual shares. Id at 191-92.

${ }^{120}$ The term "third-party sale value" is reserved for those transactions where the target and the bidder are unrelated and the negotiations over the transaction are conducted at arm's length without conflict of interest.

${ }^{121}$ See infra Part II.D. 
the directors of the firm being acquired (the "target" firm) bargain at arm's length with the acquirer (the "bidder" firm), the target's shareholders will capture some of the synergies in the sale price. Hence, in true arm's-length transactions, third-party sale value will generally be above the going concern value of the firm. Since the appraisal remedy awards going concern value, shareholders will approve third-party deals and take the merger price, rather than use the appraisal remedy.

It might be argued that $V_{3 P S}$ should be the accepted Delaware definition of fair value, rather than $V_{E}$, because it appears to be consistent with the economic concept of value. This reasoning, however, is flawed. There are multiple definitions of value, and some definitions are more consistent with the case law's use of going concern value than others. The definition of value used by economists is a version of third-party sale value - that is, the opportunity cost of the asset in its next-best use. ${ }^{122}$ The term opportunity cost is used because, if the inputs were not used by the firm, they could be deployed elsewhere. The difference in the value of the firm's inputs in an alternative use represents its opportunity cost. ${ }^{123}$ The opportunity cost concept is not a measure of going concern value, but a measure of next-best-use value.

This argument becomes increasingly muddled when its proponents point to acquisition data as a measure of the value of the firm in its next-best use-or, what we call its opportunity cost or next-best-use value $\left(V_{O C}\right)$. Opportunity cost is an equilibrium measure, and, in equilibrium, all assets are already in their best use. Consequently,

$$
V_{E}>V_{O C}
$$

That is, the opportunity cost is actually below the current use value of the assets. In equilibrium, there are no third-party offers for the company since its going concern value is higher than any alternative use.

When a change in the environment occurs and synergistic gains become available to a bidder, the firm's assets' next-best use is temporarily higher than its going concern value, reflecting the synergistic gains that will occur if the bidder succeeds in taking over the company. In other words, prior to the consummation of the merger,

${ }^{122}$ Hamermesh \& Wachter, supra note 2, at 126 (citing BREALEY ET AL., supra note 106 , at 16).

${ }^{123}$ ROBERT S. PINDYCK \& DANIEL L. RUBINFELD, MiCROECONOMICS 204 (5th ed. 2001). 


$$
V_{3 P S}>V_{E}
$$

That is, the bidder values the firm at a value greater than its going concern value.

Companies merge today and not a year ago because new opportunities have arisen that make the company undervalued in its current use. Assuming that there are no further third-party offers for the nowmerged company, the transaction returns the company to equilibrium:

$$
V_{E}>V_{o C} \text {. }
$$

Consequently, acquisition data should show that firms are bought at a premium to their going concern value. However, it is incorrect to make the logical jump that these premiums reflect some kind of IMD. The fallacy is obvious and analogous to the "dogs that don't bark" metaphor: there are lots of dogs, and most of the time, most dogs are not barking. Similarly, in any given year, the vast majority of companies are not involved in a change of control transaction. If all trading in noncontrolling shares actually reflected a discount to a firm's $V_{E}$ (going concern value), then all companies would have ready buyers all of the time. The companies in the acquisition data set, therefore, are not a representative sample. Instead, they are likely to represent the relatively few companies whose common stock does trade at a discount to $V_{E}$, or companies where synergies have emerged that make the combined company more valuable than the two companies operated separately. ${ }^{124}$

The legal rule that provides shareholders with going concern value is efficiency promoting. Value is created in change of control transactions, and the value belongs to the party that creates it. It is

${ }^{124}$ In cases involving a third-party purchaser, the negotiations involving the sale of the company typically result in the synergistic gains being shared by the buyer and the seller. See Tim Koller et AL., Valuation 435 (4th ed. 2005). Consequently, shareholders in a merger or asset sale may actually achieve a premium for their stock. However, they are not required by law to be paid the premium. See, e.g., Abraham v. Emerson Radio Corp., 901 A.2d 751, 761-62 (Del. Ch. 2006) (“[P] ure control premium envy is not a cognizable claim for a minority stockholder under Delaware law.") (citing Hollinger Int'l, Inc. v. Black, 844 A.2d 1022, 1087 (Del. Ch. 2004), aff'd, 872 A.2d 559 (Del. 2005)); Mendel v. Carroll, 651 A.2d 297, 306-07 (Del. Ch. 1994) (noting that, even though a third party offered a higher price per share than that offered by a controlling shareholder, the directors were not obligated to accept the higher price if the controller's offer was fair); Ronald J. Gilson \& Jeffrey N. Gordon, Doctrines and Markets: Controlling Controlling Shareholders, 152 U. PA. L. REV. 785, 793-96 (2003) (discussing the general corporate law standard that "a controlling shareholder can sell control at a premium that is not shared with non-controlling shareholders"). 
counterproductive to force a third-party acquirer to pay the entire acquisition premium to the acquiree's shareholders. The result would be a reduction in the number of transactions that achieve a premium price for minority shareholders. ${ }^{125}$

We are not, however, making the stronger normative claim that this is the optimal rule. We could only make this claim if the case law could reliably differentiate going-private transactions that are truly wealth creating from those that merely transfer wealth from the minority shareholders to the controller. While the courts are sensitive to this problem and can address it when plaintiffs allege a breach of fiduciary duty, underdeterrence of the misuse of inside information by controllers is possible. This is particularly true in the case of a shortform merger, where appraisal is the exclusive remedy. With all that said, as we describe below, the implicit minority discount does not address this problem; other solutions that are consistent with financial theory are available to deal with the issue.

\section{Agency Costs}

The third key concept is agency costs. To develop this concept, it is useful to differentiate between two types of firms-those where the owners are the managers, and those where there is a separation of ownership and control. The former are privately owned companies, while the latter may be either closely held corporations or publicly traded.

Adolf Berle and Gardiner Means were among the first to point out that the separation of ownership and control provides managers with discretion to further their own interests rather than the interests of shareholders. ${ }^{126}$ This separation of ownership and control results in agency costs $(A C)$, which create a difference between the values of the same firm when it is owner managed and when the managers are not the owners.

${ }^{125}$ It is similarly counterproductive to force a controller to pay a third-party sale price when exercising the right of control in purchasing the remaining shares. In particular, there is no reason to assume that such transactions are being driven by the controller's idea that the corporation's assets sell at a discount to their true value. Not every corporation is a logical acquisition candidate.

${ }^{12 i}$ See Adolf A. BERLe, JR. \& Gardiner C. MEANS, The Modern Corporation AND PRIVATE PROPERTY 119 (1932) (pointing out that "having interests in an enterprise, ... having power over it, and ... acting with respect to it" are distinct functions that individuals may fulfill to varying degrees). 
Since publicly traded (and many closely held) corporations have a separation of ownership and control, we will continue to use the term $V_{E}$ to represent the value of the equity when the firm has dispersed ownership. For contrast, we designate the value of the equity in the firm where the owners are the managers as $V_{O M}$.

We therefore have

$$
V_{E}=V_{O M}-A C \text {. }
$$

Since the work of Jensen and Meckling, it has been recognized that in transactions that disperse ownership (such as initial public offerings), the burden of the agency costs falls on the owner-managers who are separating ownership from control. As they noted,

the owner will bear the entire wealth effects of these expected costs so long as the equity market anticipates these effects. Prospective minority shareholders will realize that the owner-manager's interests will diverge somewhat from theirs, hence the price which they will pay for shares will reflect the monitoring costs and the effect of the divergence between the manager's interest and theirs. ${ }^{127}$

The agency costs thus reflect the assumption that managers will maximize their own welfare, which will not be entirely consistent with the interest of the shareholders. In its simplest terms, the owner-manager may be willing to work $24 / 7$, while the CEO with a $1 \%$ ownership stake may work more civilized hours. This divergence also explains why ownermanagers are willing to sell the company at a price that discounts the agency costs. After the transaction, the original owner-managers can work a less hectic schedule. In addition, the original owners are willing to bear the agency costs because they benefit from the ability to diversify their wealth with the cash received from the sale. ${ }^{128}$

Management actions that give rise to agency costs do not necessarily involve a violation of fiduciary duties. Agency costs are as real a cost as any other. For example, the amount of the CEO's compensation that exceeds the labor-market-clearing compensation of comparably skilled managers is an agency cost. While such compensation at times may be viewed as excessive, it is not necessarily or even ordinarily a breach of fiduciary duty. In general, the existence of agency costs

${ }^{12 \pi}$ Michael C. Jensen \& William H. Meckling, Theory of the Firm: Managerial Behavior, Agency Costs and Ownership Structure, 3 J. FIN. ECON. 305, 313 (1976).

${ }_{123}$ The agency costs are costs above the market prices required to hire comparably skilled managers. The salary and benefits paid to managers for their services as set by the labor market are regular costs and are not agency costs. Those labor market costs exist whether the firm is publicly or privately owned. 
does not imply the taking of a corporate opportunity, the use of corporate assets for private purposes, or engaging in conflicted transactions without board approval. This is not to deny that agency costs may include the effects of breaches of fiduciary duty. In our recent article, we discussed how violations of fiduciary duty should be treated in the appraisal setting, and we discuss this point in more detail in a later section of this Article. ${ }^{129}$ In general, however, agency costs are an inevitable burden on publicly held companies and largely involve no breach of fiduciary duty at all.

One immediate implication of this analysis is that if the ownership-dispersing transaction is reversed by means of a transaction that aggregates share ownership, the shareholders do not have to be compensated for the agency costs. This is true as a matter of both finance and appraisal law. The shares sold by the original owner were discounted by the amount of the agency costs, and therefore, the manager retaking the firm private should pay $V_{E}$ and not $V_{O M}$ in the goingprivate transaction. In the appraisal setting, the now-cashed-out shareholders receive the going concern value of the holdings that they sell, which are net of the agency costs.

Another implication is that the agency costs of the firm with dispersed ownership are reflected in the FCFs of the firm. The agency costs concept includes the full cost of the managers' compensation, including that part of the compensation which is above what the firm needs to pay to hire the managers in the competitive labor market. It also includes any higher supplier costs, employee labor costs, and other similar costs that the managers allow to creep into the cost structure because they bear relatively little of the loss. The agency costs concept may also include whatever revenue sources are lost if the managers are less attentive to customer needs once they are no longer the owner-operators of the firm. Finally, agency costs include the high bonding costs associated with the disclosure and other requirements of publicly traded companies.

Agency costs are thus another factor, aside from synergies, that contributes to change in control transactions. In a corporation with dispersed ownership, the agency costs show up as costs in the profit and loss statements. These costs go into the pockets (financial and psycho-

${ }^{129}$ See Hamermesh \& Wachter, supra note 2, at 145-48, 158 (arguing that "minority shareholders have a right to 'fair value' that incorporates not only current assets but also future reinvestment opportunities"); see also infra Part IV (explaining why the appraisal remedy is superior to the IMD remedy for addressing breach of fiduciary duty). 
logical) of the managers. As costs to the firm, the agency costs are a deduction from the corporation's going concern value. They also do not necessarily represent breaches of fiduciary duty. In the cash-out transaction, the reduction in agency costs accrues to the benefit of the new owner-managers because it is their actions that produce the reduction in agency costs, whether attributable to lower filing requirement costs, reduced labor or other costs, or any revenue gains.

In our discussion below, we address the normative question of whether $V_{O M}$ is superior to going concern value as a valuation standard in appraisal proceedings, particularly in transactions where a controller squeezes out minority shareholders. For now, however, we again make a more limited normative claim-namely, that reductions in agency costs arising from going private transactions are generated by the controller, not the firm, and a going concern value standard that denies the minority a share of such reductions promotes efficiency.

\section{The Benefits of Control}

In the earlier section on third-party transactions, we focused on the potential for synergies as the primary gain from a change in control. ${ }^{130}$ That is certainly the case for arm's-length, third-party transactions, but many transactions that trigger the appraisal remedy are transactions involving a controller who cashes out the minority shareholders in a going-private transaction. Do control-related benefits arise in this situation? Exploring this question helps identify benefits in third-party transactions in addition to the synergies mentioned above.

We believe that the finance evidence firmly supports a conclusion that there are benefits of control-that is, in an acquisition context, control shares can sell at a premium to noncontrol shares. This finding, however, does not logically imply that there is an implicit minority discount, as the term is used in Delaware appraisal cases. Rather, this finding merely indicates that control shares are more valuable than noncontrol shares. It does nothing to establish that noncontrol shares trade at a value less than $V_{E}$, a proposition that is the essence of the implicit minority discount claim. What we claim, however, is that the observed gap between the values of control shares and noncontrol shares is attributable to the value of control, a value that, as we explain

${ }^{130}$ See supra Part II.B (identifying synergies as a component of the sale price in an arm's-length transaction). 
directly below, is not appropriately considered part of the going concern value of the firm

In their text, Valuing a Business, Pratt et al. remark that a control block has a greater value than a noncontrolling interest because of the greater ability of the controller to direct the strategy of the firm. ${ }^{131}$ Pratt et al. list five factors that are likely to determine the size of a control premium: (1) "[ $\mathrm{t}]$ he nature and magnitude of nonoperating assets"; (2) "[t]he nature and magnitude of discretionary expenses"; (3) "[t]he perceived quality of existing management"; (4) "[t]he nature and magnitude of business opportunities that are not currently being exploited; and (5) "the ability to integrate the acquiree into the acquiror's business or distribution channels." 132

This list of causes of control premiums tells us a great deal about why control premiums are not components of the fundamental or intrinsic value of the firm. At least four of the five elements that determine the size of the differential between control shares and noncontrol ("minority") shares are not elements that a dissenting shareholder can or should recover from a cash-out transaction. Item (5) (the value of integrating acquiror and acquiree operations) is clearly a synergy and not a component of value of the acquiree on a going concern basis. Item (3) (the potential for improved management) is less a synergy, but is certainly one of the potential benefits of the change of control that cannot be attributed to the firm as a continuing concern. Why? Because improved management would not happen but for the change in control. Put another way, "existing management" (Pratt et al.'s term) is part of the company's "operative reality" (Technicolor's term) at the time of the merger. Since shareholders choose the directors who choose the managers, the shareholders do not get the value brought by a new controller who squeezes out the shareholders in order to make the management im-

${ }^{131}$ PRATT ET AL., supra note 18, at 349. We follow Pratt et al.'s treatment of the benefits of control because of the Delaware courts' regular reliance on their treatise. For recent examples of the Delaware courts' reliance on Pratt et al.'s works in their valuation analyses, see $I n r e$ PNB Holding Co. S'holders Litig., No. 28-N, 2006 Del. Ch. LEXIS 158, at *75 n.105 (Aug. 18, 2006); Gesoff v. IIC Indus., 902 A.2d 1130, 1158 n.159 (Del. Ch. 2006); Del. Open MRI Radiology Assocs. v. Kessler, 898 A.2d 290, 337 n.125, 339 n.130, 340 nn.133 \& 136 (Del. Ch. 2006); Henke v. Trilithic, Inc., No. 13155,2005 Del. Ch. LEXIS 170 , at $* 41$ n.110 (Oct. 28, 2005); Andaloro v. PFPC Worldwide, Inc., No. 20336, 2005 Del. Ch. LEXIS 125, at*65 n.68 (Aug. 19, 2005); NBC Universal, Inc. v. Paxson Commc'ns Corp., No. 650-N, 2005 Del. Ch. LEXIS 56, at *28 n.33 (Apr. 29, 2005).

132 PRATT ET AL., supra note 18, at 349. 
provement. Item (2) (the potential to reduce discretionary expenses) is simply a component of agency costs and, for reasons discussed above, should not be included in fundamental or going concern value. Item (1) (nonoperating assets) may also fall into the agency cost category because nonoperating assets are presumably potential private benefits to whomever is in control since their use does not affect earnings and other measures of business success.

The synergy-related control factors are excluded as a matter of statute, and properly so from an incentive perspective. The party that recognizes the potential synergies should benefit from them. The agency cost factors are excluded as a matter of case law, and appropriately so, since agency costs are a cost to the dispersed-ownership firm and, therefore, reduce the $V_{E}$ of the firm.

The last of the five control premium elements, item (4) (unexploited business opportunities), may be different, at least in part. In one sense, a failure to exploit business opportunities might be chalked up to poor management and treated just like other agency cost components of a control premium. However, to the extent that business opportunities are unexploited before the merger but are reasonably expected to be exploited thereafter, their value is appropriately viewed as part of fundamental or going concern value and should be recoverable by minority shareholders in most circumstances. As we explained in our recent article, assuming that the current corporate policy of the firm anticipates exploiting a business opportunity, its value then belongs to the firm and all the shareholders regardless of whether it has been exploited at the time of the merger. ${ }^{133}$ To this extent, then, item (4) should be included in the value of the existing firm as the value of the firm's corporate policy. ${ }^{134}$

Consequently, of the five factors mentioned by Pratt et al. as affecting the size of the control premium, only item (4) can be said to include an element of value that should be included in the amount received by dissenting shareholders.

${ }^{133}$ See Hamermesh \& Wachter, supra note 2, at 145-48 (arguing that even minority shareholders will be able to recover a proportionate share of reasonable expected benefits after a squeeze-out).

${ }^{134}$ See id. at 165 (including the value of unexploited business opportunities in "fair value"). 


\section{E. Summing Up: The Pratt Diagram}

The table below mirrors a useful diagrammatic treatment by Pratt et al., which graphically expresses the four finance concepts developed thus far (the value of the firm, third-party sale value, agency costs, and the benefits of control). ${ }^{135}$ The diagram also introduces another concept- "discounts"-which we explore here and more fully below. ${ }^{136}$

\begin{tabular}{|c|c|}
\hline \multicolumn{2}{|c|}{ STRUCTURE OF DISCOUNTS AND PREMIUMS } \\
\hline Value (per share) \& Valuation Method & Premium/Discount \\
\hline \multicolumn{2}{|l|}{$\$ 40.00 \ldots \ldots \ldots \ldots \ldots \ldots V_{3 p S}$ (includes synergies) } \\
\hline & $\begin{array}{c}\$ 8.00(25 \% \text { acquisition } \\
\text { premium) }\end{array}$ \\
\hline \multicolumn{2}{|l|}{$\$ 32.00 \ldots \ldots \ldots \ldots V_{o M}$ (value of control shares) } \\
\hline & $\begin{array}{c}\$ 7.00 \text { (28\% premium for control/ } \\
22 \% \text { "minority discount" for lack } \\
\text { of control) }\end{array}$ \\
\hline \multicolumn{2}{|l|}{$\$ 25.00 \ldots \ldots V_{E}$ (pro rata going concern value) } \\
\hline & $\begin{array}{c}\$ 5.00(20 \% \text { discount for lack of } \\
\text { marketability) }\end{array}$ \\
\hline$\$ 20.00 \ldots \ldots \ldots . .$. Value of unmarketable shares & \\
\hline
\end{tabular}

In this particular example, there is (1) a marketability discount of $\$ 5.00$ per share; (2) a "lack of control discount" of $\$ 7.00$ per share; and (3) a synergistic or third-party sale effect of $\$ 8.00$ per share. These three discounts reflect, respectively: (1) market illiquidity creating a lack of marketability; (2) the value of control; and (3) the synergies created in a third-party sale.

For reasons to be discussed immediately below, under Delaware law a premium of $\$ 5.00$ per share is added in appraisal to offset the illiquidity discount. ${ }^{137}$ Put another way, the Delaware case law prohibits applying a discount for lack of marketability in order to arrive at the fair value to be awarded to the dissenters. ${ }^{198}$ On the other hand, the synergies of $\$ 8.00$ per share are not added as a matter of law.

\footnotetext{
${ }^{135}$ PRATT ET AL., supra note 18 , at 347.

${ }^{136}$ See infra Part II.F.

137 PRATT ET AL., supra note 18 , at 347.
}

${ }^{138}$ See, e.g., Cavalier Oil Corp. v. Harnett, 564 A.2d 1137, 1144 (Del. 1989) (declaring that in determining the dissenting shareholder's proportionate interest in the value of the going concern, "the Court of Chancery is not required to apply further weighting factors at the shareholder level, such as discounts to minority shares for as- 
So far, none of this is controversial. The controversial part involves the so-called "minority" discount or control premium. In this example, the discount is $22 \%$ (a $28 \%$ premium), which means that the shares to the controller (absent the synergies) are worth $\$ 32$ per share, while to noncontrollers they are worth $\$ 25$. The question is whether, under Delaware appraisal law, the extra $28 \%$ belongs to the controller or whether it is a component of fair value to be shared with the minority shareholders.

As previously discussed, the shares should be appraised at a value of $\$ 25.00$ and not $\$ 32.00$. The $22 \%$ "minority discount" includes the agency costs and the additional value brought by any change in the value of management. As we explain more fully below, ${ }^{139}$ Pratt et al.'s use of the term "minority discount" can be somewhat misleading. It is evident from the context that Pratt and his colleagues are simply contrasting a valuation that is premised on possession of control (in his diagram, the $\$ 32$ "value of control" shares) and which, therefore, gives effect to "changes that only a control owner would (or could) make" from a valuation based on "income projections that merely reflect the continuation of present policies." 140

Pratt et al.'s treatment of the minority discount is on par with other leading valuation textbooks. Damodaran discusses the control premium entirely as value brought by changes in management. He differentiates between the present value of the corporation and its optimal value, where the difference reflects the changes in policy brought by management. ${ }^{141}$ In a recent article, Damodaran is more explicit, stating that "the value of controlling a firm has to lie in being able to run it differently (and better)." 142 Mercer presents a diagram similar to the one presented by Pratt et al., in which (1) the "control premium" and the "minority interest discount" are identical; (2) those adjustments equally explain the difference between "control value" and "freely tradable" "minority interest value"; and (3) the so called "minority interest value" can be derived from a DCF analysis-i.e., a valuation generated "by

serted lack of marketability").

${ }^{139}$ See infra Part III.B.

${ }^{140}$ The quoted language is from Pratt et al.'s treatment of the subject in the third edition of their treatise on business valuation, where they discuss whether a DCF analysis produces a "control value" or a "minority value." PRATT ET AL., supra note 84, at 194-95.

${ }^{141}$ DAMODARAN, supra note 105 , at 457.

${ }^{142}$ Aswath Damodaran, The Value of Control: Implications for Control Premia, Minority Discounts and Voting Share Differentials 2 (unpublished manuscript, available at http://pages.stern.nyu.edu/ adamodar/pdfiles/papers/controlvalue.pdf). 
build-up methodologies that develop capitalization rates by estimating required rates of return in relation to public markets." ${ }^{143}$

Having now seen that the so-called "minority discount" as expressed by Pratt et al. and others is simply a discount that eliminates the benefits of control, we now turn back to the question of identifying other forms of discount-namely, discounts for lack of marketability and market-related discounts more generally.

\section{F. Discounts}

The subject of discounts from fair value is a complex one, and perhaps more confusing than enlightening. Some of the complexity is generated by the informal manner in which discounts are described in appraisal cases and law review articles. Considerable mud has been added to the water, moreover, by the somewhat haphazard introduction of the IMD into Delaware appraisal law. ${ }^{144}$ We think it can be greatly simplified in the context of our Article.

We have noted three different measures of firm value: third-party sale value $\left(V_{\text {SPS }}\right)$; the fundamental value of the firm as a going concern $\left(V_{E}\right)$; and the value of the firm where the owners are the managers $\left(V_{O M}\right)$.

The short answer to the discount/premium question is the following: the shareholders should always receive the pro rata value of $V_{E}$. They do not, by law, and should not, by finance theory, receive the pro rata value of $V_{O M}$ or $V_{3 P S}$. When financial markets do not price the shares of the company such that the sum of the share value equals $V_{E}$, then adjustments need to be made. In these cases, the market has created a shareholder-level discount to the company-level $V_{E}$. Since shareholders receive the pro rata value of the corporation $\left(V_{E}\right)$, such discounts have to be offset by an adjustment.

We now turn to a brief review of market discounts that sometimes cause shares to trade at a discount to their going concern value.

\section{Illiquidity Discounts}

The one key type of discount is the one we already discussed-the discount involving illiquid securities. Indeed, once the obscurities are removed, this may be the only discount worth considering.

${ }^{143}$ MERCER, supra note 88, at 199

${ }^{144}$ For a discussion of the haphazard development of the IMD in Delaware appraisal law, see supra Part I. 
In a perfectly efficient capital market, there are no discounts from a firm's value $\left(V_{E}\right)$. But not all corporate common stock trades in efficient capital markets. Indeed, close corporations do not trade at all on a public exchange, and there is no reason to assume that the sales that are made between a willing buyer and a willing seller are at the correct price.

It is widely accepted that illiquid financial securities will sell at a discount to their proportional share of $V_{E}$ to reflect investors' preference for liquidity. ${ }^{145}$ In such cases, the aggregate sum of the value of the shares does not equal the value of the firm calculated using discounted cash flow analysis. If all dissenting shareholders in illiquid stock were paid the value of the stock, their payment would be lower than the pro rata value of the corporation.

The result would be a windfall for the controller. Fair value is the pro rata value of the corporation's $V_{E}$. If this were not the case, then squeeze-outs of illiquid positions would always generate profitable transactions for the controllers or managers who triggered the squeeze-out. ${ }^{146}$

The illiquidity discount needs to be corrected-and it is, under Delaware appraisal law. In calculating the appraisal award, the value awarded to petitioning shareholders is not reduced to reflect the illiquidity of the shares they held. Instead, they receive their pro rata value of the company, which correctly prices their shares.

\section{Closed-End Funds}

Many closed-end funds trade at a discount to their net asset value (NAV), and the discount can be both persistent and material. The source of the discount has long been debated in the finance literature without a consensus being reached. Given the lack of consensus on why closed-end funds frequently trade at a discount to their NAV, it is

${ }^{145}$ DAMODARAN, supra note 105 , at 508.

${ }^{146}$ This assertion is settled as a matter of Delaware law. See, e.g., Cavalier Oil Co.v. Harnett, 564 A.2d 1137, 1145 (Del. 1989) ("The application of a discount to a minority shareholder is contrary to the requirement that the company be viewed as a 'going concern."). In commenting on this paper, however, several finance professors took a position less favorable to minority shareholders: specifically, they not only challenged the claimed existence of an "implicit minority discount," but made the further (and not inherently implausible) claim that shares purchased at a discounted price due to a lack of marketability should be valued in a manner that gives effect to a discount for lack of marketability, and that the contrary Delaware law standard gives minority shareholders a windfall. 
unfortunate that one of the formative cases in the Delaware Supreme Court's appraisal jurisprudence concerns the going-private transaction of Tri-Continental, a closed-end mutual fund. ${ }^{142}$

In Tri-Continental, the Delaware Supreme Court identified the cause of the discount as "the inability of the common stockholder to withdraw his proportionate interest in the assets of the company." 148 This explanation is, at best, confusing. It is true that investors in open-end mutual funds can cash out at NAV. Hence, the Delaware Supreme Court's utterance is true with respect to the difference between open- and closed-end funds. The confusion occurs because closed-end funds are much more like ordinary corporations with respect to the lack of a cash-out option. If shareholders wish to terminate their investment in a corporation, they have to sell their shares in the financial market. The corporation does not ordinarily have to redeem the shares at the company's going concern value. ${ }^{149}$

Tri-Continental may thus be one of the inspirations for the IMD. Once the court accepted the argument that financial markets persistently underprice closed-end funds because of the lack of a cash-out option, then it is a simple, if faulty, logical jump to conclude that all corporations trade at a persistent discount. As discussed above, the court in Tri-Continental did not itself make this error. ${ }^{150}$

Some have suggested that the observed share price discount in closed-end funds is related to the illiquidity of the assets held by the fund. If the securities held by the closed-end fund do not trade freely in liquid financial markets, then one of the equilibrating mechanisms of market efficiency is blunted. In such a case, arbitrageurs cannot buy the underpriced closed-end fund and sell the basket of securities

${ }^{147}$ See Tri-Continental Corp. v. Battye, 74 A.2d 71 (Del. 1950).

${ }^{148}$ Id. at 73 .

${ }^{149}$ Edward B. Rock \& Michael L. Wachter, Waiting for the Omelet to Set: MatchSpecific Assets and Minority Oppression in Close Corporations, 24 J. CORP. L. 913, 921 (1999).

${ }_{150}$ See supra Part I.A (arguing that the Tri-Continental court's reasoning in considering the discount for a closed-end fund does not necessarily apply to all corporations). We do not want to push this theory too far because the court's explanation is incoherent. On the one hand, the court emphasized that the problem facing TriContinental's shareholders is that they had to sell their shares in the market in order to be cashed out. Tri-Continental, $74 \mathrm{~A} .2 \mathrm{~d}$ at 76 . At the same time, the court did not appear to believe that the securities of stock, preferred stock, and bonds held in the portfolio suffer from the same problem. Id. The court offered another explanation for the discount as well, with the explanation turning on the leverage involved in closed-end funds. Id. But here again, what is true for Tri-Continental is true for General Electric. 
held by the fund. ${ }^{151}$ However, the empirical evidence to support the illiquidity causal argument is weak. ${ }^{152}$ Moreover, here again, what is true for closed-end funds is true for corporations in general, indeed, even more so. The assets of most corporations are plant, equipment, intellectual property, and the like, and these assets are certainly more illiquid than are the securities-even illiquid securities-held by closed-end funds.

So what does explain the puzzle? To some, the discount (and the fact that it varies inexplicably over time) reflects irrationality. Others, however, offer rational explanations. For example, Berk and Stanton attribute the discount to "the tradeoff between managerial ability and fees." 153

What is to be made of the different explanations? Suppose that Berk and Stanton are correct in their assessment of the closed-end fund puzzle. Their explanation is equivalent to an agency cost explanation: managers may take in fees more than they deliver in performance. Closed-end funds, in this way, are like regular corporations with managers who may have a better or worse than average ability to manage. Unlike open-end funds where the number of shares outstanding contracts when they do poorly, the closed-end funds have a fixed number of shares, so only the value of the shares changes. Hence, the badly performing closed-end fund managers are like badly performing managers of corporations. If the market anticipates that poor management will continue, then the discount appears and can persist. ${ }^{154}$

${ }^{151}$ See Berk \& Stanton, supra note 34, at 3 ("If a fund owns a lot of restricted stock or other illiquid assets, which do not trade freely, its NAV may not accurately reflect its true value, in which case the fact that it does not trade at its NAV is not particularly surprising."). Tri-Continental appears to be such a case. Tri-Continental's portfolio consisted of bonds and preferred stock that equaled $60.8 \%$ of the portfolio; the remaining $39.2 \%$ was in common stock. Tri-Continental, $74 \mathrm{~A} .2 \mathrm{~d}$ at 73.

${ }^{152}$ See Berk \& Stanton, supra note 34 , at 3 (" $[\mathrm{H}]$ oldings of restricted stock do have some explanatory power for discounts, but these holdings are small or zero for most funds, so cannot fully explain the "anomaly."). Moreover, while the securities held by Tri-Continental may have been illiquid, the assets of most operating companies are even more illiquid. Assets of operating companies are heavily plant- and equipmentrelated, and these assets rarely trade freely in secondary markets.

${ }^{153} I d$. at 2.

${ }^{154}$ The method for calculating the $V_{E}$ of the closedend fund raises difficult empirical questions, but is conceptually the same as the problems normally confronting the appraisal court. The contending parties will present alternative calculations of the fund's $V_{E}$. Presumably, the respondent is the closed-end fund itself, which is engaged in a goingprivate transaction. In that case, the respondent's expert will do what respondent experts normally do, which is to paint a bleak picture of the future return of the fund, and the petitioner's expert will argue the opposite. The difference from the traditional case is that the evidence will be based on the fund's market price, which presumably incorpo- 
Because the Berk and Stanton explanation is generally true for corporations, the closed-end story fits squarely with the agency cost explanation developed above. The only difference is that agency costs may be more visible in the closed-end context because the performance of closed-end managers-their ability to outperform the markets versus the fee they charge for managing the portfolio-is more observable than the performance of corporate managers.

There are no new implications for Delaware appraisal law: shareholders receive the pro rata value of the corporation's $V_{E}$. In other words, shareholders should receive an award that includes either the extra costs or the extra benefits created by management's performance. In neither situation should the effect be understood as a "discount" or a "premium." Any reduction in value, so explained, is not due to illiquidity or market inefficiency. The costs or benefits are real and should be included. Hence, in the case where value is reduced, the shareholders should receive the reduced amount. They paid (presumably less) for poor managers, and they are charged for it. ${ }^{155}$

The agency cost explanation of the discount for closed-end funds contains an element of irrationality on the part of the original purchasers of the newly issued shares. The irrationality is that these closed-end funds are normally sold at their NAV and then open trading at a discount to their NAV. These original investors lose out.

But this does not pose a problem for appraisal analysis. Investors who buy shares at a premium to the corporation's $V_{E}$ are not protected. Indeed, the irrationality argument on the part of the original investors is a small slice of a bigger story that emphasizes occasional

rates the market's assessment of the costs and benefits of the fund manager.

${ }^{155}$ It is certainly conceivable, on the other hand, that a firm that is unusually well managed by a controlling shareholder may have minority shares that trade at a price greater than what the share price would be if the firm's ownership were widely dispersed and subject to control by less capable management. Indeed, one suspects that this may be the case with respect to Berkshire Hathaway under Warren Buffett's management. While not asserting that Berkshire Hathaway's stock has been overvalued in relation to its intrinsic value (which he defines as "the discounted value of the cash that can be taken out of a business during its remaining life," BERKSHIRE HATHAWAY INC., ANNUAL REPORT 77 (2006), available at http://www.berkshirehathaway.com/ 2005arn/2005ar.pdf), Warren Buffett has insisted that "fairness prevails when market price and intrinsic value are in sync" and that managers can help bring about this result through their policies and public communications. Letter from Warren Buffett, Chairman, Berkshire Hathaway Inc., to Shareholders of the Corporation (Feb. 28, 1997), available at http://www.berkshirehathaway.com/letters/1996.html. At the very least, then, Buffett clearly rejects the IMD premise of inherent undervaluation in share market prices. 
market irrationality in the pricing of stocks, especially in initial public offerings. ${ }^{156}$ In the broader context, irrationality is ambidextrous and can give rise to discounts or premiums. Appraisal law appropriately ignores both when it adheres to its standard of awarding the proportionate share of the corporation's $V_{E}$.

\section{Nonvoting Stock}

The question of how to treat nonvoting stock, restricted stock, and different classes of stock in general raises continuing problems. Different classes of stock have differential control or economic rights, as well as different limits on market liquidity. While Delaware law has properly stated that there is no discount for market illiquidity, the position may be different with respect to voting and economic rights.

Take the case of a class of common stock that has no voting rights, but does have the same dividend rights and a residual claim equal to that of the voting stock. In many such cases, the voting stock sells at a premium to the nonvoting stock, perhaps reflecting the probability that the holders of the voting stock will exercise their rights to sell the stock at a premium in a change of control transaction.

Suppose, however, that in a cash-out merger the voting stock is not cashed out at a premium, and the holders of the voting stock perfect their appraisal rights. Should they be awarded a premium over their proportionate share of the corporation's aggregate $V_{E}$ ? Alternatively stated, should the nonvoting stock be discounted relative to $V_{E}$ ? In this case, the legal rule that the shareholders have a right to their pro rata going concern value provides one clear answer to these questions. Specifically, since the two classes of stock enjoy equal residual claims to the corporation's free cash flow and share equally in any asset sale or liquidation, both should be accorded the same value in appraisal. A different rule would require recognizing and giving valuation effect to characteristics of the shares themselves, an approach that seems inconsistent with prevailing doctrine precluding premiums or discounts at the "shareholder level." ${ }^{157}$

${ }^{1556}$ See generally ANDREI SHLEIFER, INEFFICIENT MARKETS: AN INTRODUCTION TO BEHAVIORAL FINANCE 112-53 (2000) (surveying psychological and institutional evidence that investors do not always behave rationally).

${ }^{157}$ See generally Rapid-Am. Corp. v. Harris, 603 A.2d 796, 801, 80406 (Del. 1992) (discussing the distinction between value at the corporate and shareholder levels); Cavalier Oil Corp. v. Harnett, 564 A.2d 1137, 1144-45 (Del. 1989) (noting that Dela- 
The equal treatment rule suggested above, however, may prove too much. We do not discuss in this Article the more complex problem that arises in the case where the classes of stock differ as to their dividend rights or residual claims in liquidation. In this case, the classes of stock could quite appropriately be accorded different values in appraisal, yet such differential treatment similarly offends a broad prohibition against taking into account characteristics that operate at the "shareholder level." Exactly how or whether that differential treatment might be implemented, however, is beyond the scope of this Article.

\section{The Treatment of FinanCE In DELAWARE APPRAISAl LaW}

\section{A. Consistent with Finance, but with One Exception}

Delaware appraisal law is consistent with the modern finance that it implements ${ }^{158}$ in most respects. In modern financial theory, the value of the corporation-the going concern value in legal terms-is calculated as the discounted future cash flows generated by the company's assets. $^{159}$ In the appraisal remedy, the favored method for calculating the fair value of the corporation is the preferred method in finance for calculating the value of the corporation-that is, the discounted future free cash flows or DCF. ${ }^{160}$ In both finance theory and the appraisal remedy, the value of a shareholder's stock is the pro rata value of the discounted future free cash flows (again using the simplifying assumption that the corporation's investment is entirely equity).

ware case law allows discounts or premiums at the corporate level, but not at the shareholder level).

${ }^{158}$ As required by Weinberger $v$. UOP, Inc., 457 A.2d 701, 712 (Del. 1983).

159 See supra notes 119,155 , and accompanying text.

160 See supra note 6 and accompanying text.

${ }^{161}$ See PRATT ET AL., supra note 18, at 31 (defining intrinsic value as "based on the perceived characteristics inherent in the investment"). The fundamental value of the firm is also close to the legal term "intrinsic value," although that term implies some value that is inherent in the assets themselves and, perhaps, suggests that there is a single number rather than a range of values. Indeed, if the required data were known precisely, the corporation being appraised would have a single value, representing its $V_{E}$. Of course, the required information, since it represents estimates of the future, cannot be known with precision. Informed individuals can have different views about the future free cash flows and the appropriate discount rate. Hence, the result, empirically speaking, is a range of values that define the corporation's $V_{E}$. This is the rationale behind the traditional practice of using a number of alternative methods and reasonable assumptions to create a range for the company's going concern value. See BREALEY ET AL., supra note 108, at 253-56 (describing the Monte Carlo simulation 
In addition, the case law embeds the finance treatment of agency costs. ${ }^{162}$ The DCF method calculates the value of the firm net of agency costs. Hence, the court awards shareholders the going concern value, or $V_{E}$, which is net of agency costs. The same can be said for the value of control. As discussed above, the value of control includes both agency costs and the costs associated with synergies or gains that would occur in a change of control transaction. Once the case law adopts the DCF method to estimate the value of the company (Equation (3)), implicit in the courts' conclusion is the recognition that what petitioning shareholders receive excludes the benefits of control and includes the effect of agency costs.

Delaware's appraisal law has also incorporated modern finance theories in determining the appropriate discount rate. The discount rate used in appraisal proceedings is typically estimated using the capital asset pricing model (CAPM) and the weighted average cost of capital (WACC). ${ }^{163}$ Indeed, the Court of Chancery is so informed by current thinking that it applies a version of the three-factor CAPM theory. In particular, it will add to the discount rate an estimate of the excess returns experienced by small stocks. ${ }^{164}$ It also attempts to adjust for the discount rate effects caused by the higher probability of bankruptcy in highly-leveraged firms. ${ }^{165}$ Finally, when using comparable companies to estimate the company's cost of capital, the court dutifully adopts the mechanics of the unlevering-relevering process. ${ }^{160}$ The problems that arise with respect to estimating the discount rate

method, which produces a range of values to accommodate forecasting error).

${ }^{162}$ See supra Part II.C (discussing the financial theory of agency costs).

${ }^{163}$ See, e.g., Del. Open MRI Radiology Assocs. v. Kessler, 898 A.2d 290, 338-39 (Del. Ch. 2006) (discussing the role of CAPM and its tensions with the "build-up model" in estimating WACC); Lane v. Cancer Treatment Ctrs. of Am., No. 12207, 2004 Del. Ch. LEXIS 108, at*113-14 (July 30, 2004) (describing the CAPM method of deriving cost of equity in estimating WACC).

${ }_{164}$ See, e.g., Gesoff v. IIC Indus., 902 A.2d 1130, 1159 (Del. Ch. 2006) ("The smallsize premium, although somewhat controversial, is a generally accepted premise of both financial analyses and of this court's valuation opinions."); Del. Open MRI, 898 A.2d at $338 \mathrm{n} .129$ (supporting the use of a premium on small-size stocks, despite the "great debate" over whether it is appropriate); ONTI, Inc. v. Integra Bank, 751 A.2d 904, 920 (Del. Ch. 1999) ("This court has traditionally recognized the existence of a small stock premium in appraisal matters.").

${ }^{165}$ Union Ill. 1995 Inv. Ltd. P'ship v. Union Fin. Group, Ltd., 847 A.2d 340, 362-63 (Del. Ch. 2003) (applying the three-factor Fama and French CAPM model because it "helps capture the risk associated with possible insolvency and other problems in highly leveraged firms").

${ }_{166}$ See, e.g., Andaloro v. PFPC Worldwide, Inc., No. 20336, 2005 Del. Ch. LEXIS 125 , at *58 (Aug. 19, 2005). 
for the types of companies involved in appraisal are well beyond the scope of the present Article, but it is clear that the Delaware courts attend studiously to financial expertise in identifying and resolving those problems.

So far so good: generally accepted finance principles and the Delaware valuation case law are consistent. Data limitations prevent the courts from exactly replicating modern finance's valuation theory, but otherwise they reasonably track any of the textbooks. But then the remarkable divergence occurs. In adopting the IMD, the Delaware courts explicitly or implicitly assert, as a matter of finance, that while the value of the firm is the discounted free cash flows, the common stock of corporations-even in the most informed and liquid financial markets-is persistently and consistently priced at values below the pro rata value of the free cash flows. ${ }^{167}$

If this were true, then the courts would be correct in mistrusting the comparable company analysis for valuing firms. There is no finance textbook, however, that supports this proposition. To the contrary, most textbooks assume that for companies that trade in informed and liquid markets, the value of the stock is the pro rata value of the company. ${ }^{168}$ No discounts or premiums need to be added or subtracted from the equation. If the IMD were correct as a matter of finance, the textbooks would say that the common stock is first valued at the pro rata value of the company's free cash flows, but then discounted by approximately $30 \%$ since only minority shares are being traded. But we are unaware of any textbooks that make such a claim.

Consequently, the only weed in this otherwise beautiful garden of finance methods is the IMD. How could the courts, after dutifully following the dictates of Weinberger to apply current methods of finance, have latched onto the IMD? As we discussed in the section on case law, ${ }^{169}$ the courts believe (or have been led to believe) that they are being faithful to finance theory when applying the IMD. That is, the courts believe that

167 See supra Part I.D. Put mildly, the IMD is thus in tension with the observation by the Delaware Supreme Court that "a well-informed, liquid trading market will provide a measure of fair value superior to any estimate the court could impose." Applebaum v. Avaya, Inc., 812 A.2d 880, 890 (Del. 2002).

${ }^{168}$ See supra notes 118-119; see also Carney \& Heimendinger, supra note 21, at 85758 ("The basic conclusion of the Efficient Capital Markets Hypothesis (ECMH) is that market values of companies' shares traded in competitive and open markets are unbiased estimates of the value of the equity of such firms.").

${ }^{169}$ See supra Part I. 
they are applying finance theory when they recognize the IMD and adjust for it. How is it that they arrived at this position?

\section{B. The Supposed Finance Behind the IMD}

To be fair, the Delaware courts did not invent the IMD; some of the experts who testified in appraisal proceedings presented the IMD concept to the courts, as we have already reviewed. ${ }^{170}$ What was their reference point? The main reference point was the case history discussed above, which emphasizes the happenstance involving the expert testimony that allowed the IMD concept to take root. Certainly aiding this process was the courts' longstanding distrust of market prices, a perspective also emphasized above.

A frequently cited academic reference for the IMD is John Coates. In his article, Coates says that if courts determine fair value using actual trading prices for comparable companies, then those trading prices include a financial discount. ${ }^{171}$ The result is that a market multiple determined in this fashion will be too low because it reflects the discount. Consequently, the comparable company method will understate fair value. Coates, however, appears to accept the IMD as an empirical regularity and does not present an analysis of the finance behind the IMD. Coates's only reference for this IMD claim is Pratt et al.'s assertion that "[i]f conditions in the market for companies in the industry at the valuation date are such that controlling interests can be sold for more than the aggregate value of the publicly traded minority shares, then a control premium probably is warranted if valuing a controlling interest." ${ }^{172}$

This assertion is unquestionably true. But it advocates application of a premium only when "a controlling interest" is being valued; it says nothing to the effect that noncontrolling shares necessarily trade at prices below the $V_{E}$ of the firm. The only reason one could conclude that it does suggest such an adjustment is that it uses the term "minority shares." In Delaware's jurisprudence, discounts due solely to minority status are not allowed because the shareholders should receive the pro rata value of the going concern. Like a number of other finance experts, however, ${ }^{173}$ Pratt et al. use the term differently, purely

${ }^{170}$ See supra Part I.

${ }^{171}$ Coates, supra note 28 , at 1265 \& n.46.

${ }^{179}$ PRATT ET AL., supra note 84, at 304-05.

${ }^{173}$ See supra notes 141-143 and accompanying text (discussing alternative interpretations of "minority shares" by other scholars). 
to distinguish valuations of control blocks from valuations of shares generally. Thus, in Pratt et al.'s discussion, the term "minority" as a basis for valuing shares is applied to valuations, whether achieved through the use of DCF analysis or a comparable company analysis.

By the fourth edition, Pratt et al.'s treatment is very different. Now, the authors are leaving nothing to chance. While the third edition was perhaps understandably misquoted to support the existence of an IMD, the fourth edition cannot be so used. First, the authors discuss how price to earning $(\mathrm{P} / \mathrm{E})$ ratios, one of the key market multiples used in comparable company analysis, vary considerably over time and how takeover premiums vary inversely with $\mathrm{P} / \mathrm{E}$ ratios. Specifically, they point out that share markets may overprice as well as underprice: "Many times individual stocks, and even entire industries, may be overpriced. . . . In such instances, a public market noncon trolling interest stock price may be equal to-or even greater than-a controlling interest stock price." ${ }^{174}$ Then, the authors formally refute the rote addition of the IMD. Specifically, they state that "[v]aluation analysts who use the guideline public-company valuation method and then automatically tack on a percentage 'control premium' ... had better reconsider their methodology."175

In short, we submit that the Delaware courts, Coates, and others ${ }^{176}$ have mistakenly attributed to Pratt et al. a claim-that the IMD systematically exists - that they never made and that they now clearly disavow. If there is any other financial scholarship on which the courts or experts have relied to assert the existence of the IMD, it has not come to our attention.

${ }^{174}$ PRATT ET AL., supra note 18, at 355.

${ }^{175}$ Id. at 357 (citing Shannon P. Pratt, Control Premiums? Maybe, Maybe Not-34\% of 3rd Quarter Buyouts at Discounts, SHANNON PRATT's BuSINESS VALUATION UPDATE, Jan. 1999, at 1, 1-2).

${ }^{176}$ Professor Hamermesh was one of these "others." Commenting on Kleinwort Benson Ltd. v. Silgan Corp., No. 11107, 1995 Del. Ch. LEXIS 75 (June 15, 1995), Hamermesh observed in 1995 that "the unadjusted use of comparative market analysis as a measure of 'fair value' improperly substitutes a market value approach for the 'proportionate share of enterprise value' approach, and will tend to understate 'fair value." Chancery Court Appraisal Increases Market Value To Reflect Enterprise Value but Otherwise Accepts Respondents' Claims and Adopts Valuation Below Merger Consideration, 14 Bank \& Corp. Governance L. Rep. (Computer L. Rep.) 860, 863 (1995). The fatal flaw in this comment was its unsupported assumption that a share lacking control necessarily has a value substantially below the proportionate share of the going concern. 


\section{Why the Delaware Bench and Bar Fell into Error}

Before concluding that the Delaware courts should return to their initial rejection of the IMD, we consider it worthwhile to examine why these courts might be reluctant to abandon the concept, and why they might have been inclined to adopt it as they have.

Most directly, we suspect that the Delaware courts' embrace of the IMD has arisen from the following two-step syllogism. The first step is unexceptionable: A controlling block of shares ordinarily has a value in excess of $V_{E}$, or going concern value. ${ }^{177}$ This value arises from legal rights enjoyed by a controller. The bundle of control rights includes the ability to squeeze out the minority at any time the controller chooses. It also includes the controller's right to sell control at a premium to the shares' market value.

The second step is the inference that shares that are not part of a controlling block therefore trade at a price less than their proportionate share of $V_{E}$. The acceptance of this second step was made much easier by the work of analysts, like Pratt et al., who characterize appraisals of noncontrol shares as "minority valuations." ${ }^{178}$ The second step has also been helped along by the suggestion that minority shares of a corporation that has a controlling shareholder tend to trade at a discount relative to the $V_{E}$ of the firm. ${ }^{179}$ Accordingly, the characterization of a valuation as a "minority valuation" tended to lead practitioners and judges into thinking that shares lacking control necessarily trade at a discount to $V_{E}$.

But the second step does not follow logically from the first. As discussed, the relevant question is, "Who owns the value that goes with control?" The answer is that control rights can only be owned by a controller. Take the case of a publicly traded company that has no controller. Efficient market theory states that the shares of this company trade at the pro rata value of the corporation as a going concern. ${ }^{180}$ Without a controller, there is no value of control embedded in the stock price. Enter a would-be controller who bids for the stock. It is the entrance of the controller that creates any potential control value-by capturing synergies with the assets already owned by the new controller or by reducing agency costs through managing the company differently.

\footnotetext{
${ }^{177}$ See supra Part I.D.

178 See supra Part I.D.

179 See supra note 36 and accompanying text.

${ }^{180}$ Carney \& Heimendinger, supra note 21, at 857-58.
} 
Noncontrolling (so-called "minority") shares thus do trade for less than control shares involved in a change of control transaction. The reduction in agency costs means that the private corporation has a higher value ( $V_{O M}$ instead of $V_{E}$ ) than does the public company. But does this suggest a wrongful discount?

The answer is that there is no discount to going concern value, let alone a wrongful discount. The gains from the transaction would not exist but for the going-private transaction and, consequently, the gains belong to the acquirer by statute. ${ }^{181}$ Similarly, the gains in the goingprivate transaction are not double-dipping from a finance perspective. The initial owner-managers received a price in selling the shares that bore the burden of anticipated agency $\operatorname{costs}^{182}$ and, hence, ownermanagers buying back the shares should be able to pay a price that likewise bears the burden of such agency costs. In both transactions, the shares trade at the firm's $V_{E}$ with the firm constituted as a publicly held firm. The minority shareholders therefore do not and should not get either the benefit of the newly private company's reduction of agency costs or the benefits of control.

What the IMD accidentally accomplishes is to introduce a "thirdparty sale value lite" standard in lieu of the traditional "proportionate share of going concern value" standard. Under this "third-party sale value lite" standard, courts invoking the IMD take a CCA result and add a premium based on company acquisition data, and from that result they deduct some estimate of synergies. ${ }^{183}$

Third-party sale value lite is thus similar to our $V_{O M}$. That is, while the dissenting shareholders do not get the synergies, they do get the benefits of control (in the form of reduced agency costs) that arise as a consequence of the transaction. However, $V_{O M}$ is clearly not the valuation standard established in Delaware appraisal law because it awards not going concern value, but the additional value that is created by the transaction.

From an efficiency perspective, replacing going concern value with $V_{O M}$ would promote some inefficiencies because it would deincentivize value-enhancing transactions, as those who promote the efficiency gains would not be rewarded for their action. However, $V_{O M}$ does have distributional aspects in terms of affording better protection to minority shareholders' interests. If one believed that the

${ }^{181}$ See DEL. CODE ANN. tit. 8, § 262(h) (2006).

${ }_{182}$ See Jensen \& Meckling, supra note 127, at 313.

${ }^{183}$ See supra note 101 and accompanying text. 
courts' use of the financial tools led them to systematically undercompensate minority shareholders, then $V_{O M}$ would ameliorate the problem. We discuss this issue in greater detail in the next section.

There may be another explanation, based on the concept of asymmetric information, for the Delaware courts' willingness to embrace the idea that market prices do not reflect the going concern value of the company. That is, managers know more than the market and can manipulate information to their advantage. Since managers are better off financially and enjoy greater job tenure when their publicly traded shares trade at a high value, they have an incentive to overstate the good information and hide the bad information. ${ }^{184}$ It might be argued, then, that this leads to publicly traded shares trading at a discount ${ }^{185}$ since the market overreacts, negatively, to the prospect of managerial overoptimism or concealment of bad news.

While the argument is correct as to the existence of asymmetric information, it holds no obvious implications for the question of whether market prices reflect going concern value. Suppose all corporations wear comparably rosy glasses. When the market learns the color, it will adjust all market prices accordingly. The market adjusts to systematic bias in the predictions of corporate managers.

Of course, the analysts and investors may incorrectly settle on a discount to apply to individual companies, but there is no reason to assume that the discount is always too low. In fact, the bias has to be unsystematic because the market can price in any systematic bias. In other words, the market may sometimes discount by too much or too little, and since there is no reason for the market to bias its incorrect estimates in either direction, the errors will not lead to a systematic underpricing of publicly traded shares.

Moreover, if one assumes that companies' public pronouncements are made with rose-colored glasses, then the most suspect projections would be those of the company being appraised. This would cause the appraised company's own projections to be faulty. However, management projections prepared prior to the company's decision to squeeze out the minority shareholders are treated by the court as the

${ }^{184}$ Donald C. Langevoort, Resetting the Corporate Thermostat: Lessons from the Recent Financial Scandals About Self-Deception, Deceiving Others and the Design of Internal Controls, 93 GEO. L.J. 285, 306-08 (2004).

${ }^{185}$ Coates makes the asymmetric information argument. Coates, supra note 28 , at 1276 \& n.80 (citing Victor Brudney, Efficient Markets and Fair Values in Parent Subsidiary Mergers, 4 J. CORP. L. 63, 71 (1978)). 
most reliable evidence of the going concern value of the company, ${ }^{186}$ and appropriately so. Projections made in a neutral setting, prior to a decision to squeeze out minority shareholders, provide reliable evidence of the firm's going concern value. In the IMD, however, it is the stock price of the comparable companies that is under a cloud of suspicion. Consequently, for the asymmetric information argument to serve as support for the IMD, the untenable premise has to be that financial markets are not only systematically biased, but are also biased in the same direction all of the time.

Alternatively, suppose that the courts want to buy into behavioral finance, which suggests that stock market prices reflect human errors as well as DCF or, indeed, any theory that allows for systematic market inefficiencies. Even with this supposition, the IMD fares no better. Behavioral finance does not at all suggest a systematic underpricing of stocks. Indeed, since the year 2000 , behavioral finance has become more popular, as a means of explaining irrationally exuberant stock prices. ${ }^{187}$ The claim then was that stock prices were far in excess of any rational set of assumptions with respect to the growth rate or discount rate used to calculate the corporation's discounted free cash flows. The same is true of any theory of market inefficiencies. If markets are inefficient, as originally suggested by the Delaware courts in Chicago Corp. v. Munds, ${ }^{188}$ then "dejected melancholy," otherwise known as the IMD, gives way from time to time to "exhilarated enthusiasm."

In short, any theory with respect to market mispricing of stock in relation to going concern value has to allow for stock prices that are "too high" as well as "too low." The implication for appraisal law is that the court could never simply assert an IMD of $30 \%$, or any other value. Instead, the court would have to adopt a case-by-case approach, with experts opining on whether they believe that market prices for comparable companies are either higher or lower than the pro rata

${ }^{186}$ See, e.g., Doft \& Co. v. Travelocity.com, Inc., No. 19734, 2004 Del. Ch. LEXIS 75 , at *21-22 (May 21, 2004) ("Delaware law clearly prefers valuations based on contemporaneously prepared management projections because management ordinarily has the best first-hand knowledge of a company's operations."), reconsideration granted, 2004 Del. Ch. LEXIS 84 (June 10, 2004); Gilbert v. MPM Enters., 709 A.2d 663, 669 (Del. Ch. 1997) (accepting management forecasts for DCF purposes absent evidence of unreliability), affd, 731 A.2d 790, 798 (Del. 1999).

${ }^{187}$ See, e.g., ROBERT J. SHILLER, IRRATIONAL EXUBERANCE, at xi-xii (2000).

188 I72 A. 452, 455 (Del. Ch. 1934) ("There are too many accidental circumstances entering into the making of market prices to admit them as sure and exclusive reflectors of fair value."). 
value of their equity. We think that these are not waters into which the Delaware courts will wish to plunge.

\section{Pulling Up the WeEd: Does Rejecting the IMD Impair the UTILITY OR FAIRNESS OF THE APPRAISAL REMEDY?}

We suspect that those who would advocate the continued use of the IMD or, even more extreme, the adoption of a third-party sale value standard, also hold that conventional financial analysis is inadequate to the task of protecting against opportunistic conduct by controlling stockholders. We are sympathetic to this concern, but, as discussed in this Part, we believe that the IMD is the wrong tool, conceptually and practically, to address it.

First, we find this concern attenuated, at best, in cases involving a cash-out merger of a corporation without a controlling stockholder. In cases without a controlling shareholder, the law governing control transactions that cash out existing shareholders provides other sources of protection. The shareholder vote on the merger affords a considerable check on abuse, ${ }^{189}$ as does the fiduciary duty of the board of directors, which requires the directors to obtain the highest current value reasonably available for the shares. ${ }^{190}$ Indeed, assuming that the board acts appropriately, the cashed-out shareholders are likely to receive some of the synergy value (in $V_{3 P S}$ ) and some of the value of control inherent (in $V_{O M}$ ). More generally, any time that the squeeze-out transaction involves a firm without a controlling shareholder, the market for corporate control can work its magic as long as the board fulfills its fiduciary duty to maximize the sale price.

The same is, or at least should be, true even in the case where the going-private transaction is initiated by the current management. By offering to buy the company for cash, the inside-managers-turnedbuyers have triggered Revlon duties. ${ }^{191}$ Independent directors should shop the company so that shareholders are likely to receive third-party sale value for their shares. This, then, is not a problem case.

${ }^{189}$ See DEL. CODE ANN. tit. 8, $\$ 251$ (c) (2006) (requiring the approval of a majority of outstanding shares for a merger).

${ }^{190}$ See Revlon, Inc. v. MacAndrews \& Forbes Holdings, Inc., 506 A.2d 173, 182 (Del. 1986) (holding that in a sale of the company, directors have a duty to obtain the highest reasonably available current value).

${ }^{191}$ See, e.g., Mills Acquisition Co. v. Macmillan, Inc., 559 A.2d 1261, 1282 (Del. 1989) (noting directors' duty "to obtain the highest price reasonably available for the company," where two directors and senior officers were participants in the challenged leveraged buy-out). 
The more troublesome case is where an existing controller chooses to take the company private. Any independent members of the board of directors can no longer shop the company because the controller can vote its shares and block any merger other than the one it is proposing. ${ }^{192}$ This is a right of control, and it is not wrongful.

The board does have an obligation to secure a fair value for the shares, and any purchase price is subject to entire fairness scrutiny, even if the decision is made by the disinterested board members. ${ }^{193}$ In addition, dissenting minority shareholders can seek appraisal or quasiappraisal in the case of a successful allegation of wrongful behavior by the controller. ${ }^{194}$

Even so, we are concerned by the possibility of wrongdoing. The problem is that the additional check afforded by the market for corporate control does not exist. The only possible transaction is the one proposed by the controller, even if another bidder were to propose a more attractive offer. Consequently, we worry that the controller may try to steal the company from the minority shareholders by offering too little; that is, by offering less than the company is actually worth $\left(V_{E}\right)$.

It is this problem of controller wrongdoing that focuses attention on the efficiency of the legal rule. If the controller can use its informational advantages, it may be able to take the company private without paying going concern value. How can this problem be offset? Does the IMD provide a solution? If the IMD provided a remedy to this problem, then perhaps its failings in finance theory could be overlooked.

The IMD, however, is not well tailored to dealing comprehensively or rationally with the problem of controller opportunism. Its most obvious shortcoming in this regard is that it addresses only one algorithm-comparable company analysis-used to estimate going concern value. If the DCF analysis is used, then the IMD is not applied. Worse yet, the IMD is aimed at the wrong target if information asymmetry is the perceived problem. It is a deep stretch to say that the comparable company analysis, compared to the DCF, is particularly susceptible to undetectable manipulation by the controller, and the

192 See, e.g., McMullin v. Beran, 765 A.2d 910, 919 (Del. 2000) (recognizing that the board is unable to seek an alternative transaction opposed by a majority shareholder).

${ }^{193}$ See Kahn v. Lynch Commc'n Sys., Inc., 669 A.2d 79, 84 (Del. 1995) (describing the "fair dealing and fair price" standard in entire fairness scrutiny); Gesoff v. IIC Indus., 902 A.2d 1130, 1144 (Del. Ch. 2006) (explaining that the entire fairness review serves to protect the interests of minority shareholders).

194 Cesoff, 902 A.2d at 1155 (assessing fair value for purposes of determining damages for a controller's breach of fiduciary duty). 
courts make no such claim. If anything, the comparable company method is more open to contestable claims since neither side has inside information with respect to the would-be comparables.

We claim that a solution that addresses the problem has to be specific to the potential opportunism of controllers. This problem is not rooted in the trading of publicly traded companies. Instead it is rooted in the behavior of the firm being appraised, and where this problem is most severe is in the case of a firm with an existing controller.

One standard that does potentially address this problem is the $V_{O M}$ standard discussed above. Critically, and unlike the misdirected IMD, it focuses on the potential problem-namely, that the minority shareholders are receiving less than the value of what is being taken from them. This could result from any of the agency cost factors discussed above, including a planned diversion of a corporate opportunity or excessive compensation for the managing controllers. While most agency costs are perfectly legitimate costs associated with public ownership, agency costs will also include those excessive costs of selfdealing that would be breaches of fiduciary duty if fully detected by shareholders and sanctioned by the court in a fiduciary duty suit.

If applied like a mandatory IMD, however, the $V_{O M}$ standard would be excessively restrictive of perfectly legitimate going-private transactions. Fortunately, there is no need to change valuation standards because the going concern standard already allows for the inclusion of the elements discussed above.

The adversarial appraisal hearing already allows the petitioners' expert to offer alternative forecasts for the horizon period for which annual forecasts are available or for the growth rate of the terminal value. In Travelocity, for example, the IMD was applied in a context where it largely offset the inferior market position and future growth prospects of the firm. ${ }^{195}$ The court may appropriately have been concerned that Travelocity was being taken private as a prelude to the exploitation of opportunities already available to the firm to improve its market share. ${ }^{196}$ If that were the concern, the IMD may well have led to a correct valuation result. Under the approach we suggested in our previous article, however, the IMD adjustment is unnecessary: the potential to

${ }^{195}$ Doft \& Co. v. Travelocity.com, Inc., No. 19734, 2004 Del. Ch. LEXIS 75, at *4-6 (May 21, 2004) (describing Travelocity's inferior market position relative to Expedia and its limited ability to develop the "merchant model business"), reconsideration granted, 2004 Del. Ch. LEXIS 84 (June 10, 2004).

${ }^{196}$ See id. at *22-23 (noting that management had dismissed its own favorable DCF projections as unreliable). 
exploit opportunities available to the existing firm can be taken into account in determining fair value, because the squeeze-out transaction itself would not have been critical to the realization of the firm's potential. If these were the facts, then the Travelocity court could reach the same valuation result-not by applying the IMD, but instead by accepting the petitioners' claims as to the prospects of the firm. ${ }^{197}$

Specifically, what we suggested is that there may be cases where the profit realized from the transaction occurs because of a diversion of a corporate opportunity or other breaches of fiduciary duty. ${ }^{198} \mathrm{Al}-$ though these profits do not occur immediately and are not already generating profits for the company, they are profits that arise from implementing a corporate plan that is already available to the managers and does not require the merger to implement. That is, the profits are not "but for" the merger, and cash flow projections can and should be adjusted to take such profits into account. ${ }^{199}$ The controller accordingly does not and should not benefit at the expense of the minority by taking the value of what belongs to the corporation and its shareholders as a whole. ${ }^{200}$

\section{CONCLUSION}

The "implicit minority discount," or IMD, is a fairly new concept in Delaware appraisal law. A review of the case law discussing the concept, however, reveals that it has emerged haphazardly and has not been fully tested against principles that are generally accepted in the financial community-the principles that Weinberger has wisely called upon the courts to accept. In a body of jurisprudence that generally attends to the teachings of modern finance-particularly in its use of discounted future free cash flows as the appropriate measure of going concern value-the IMD stands out as a concept that is foreign to, and inconsistent with, finance theory.

Perhaps the introduction of the IMD concept into the Delaware case law was facilitated by the allure of misleading terminology. By correctly noting that control share blocks tend to be more highly val-

${ }^{197}$ See id. at *18,*48 (stating that the court's fair value determination was $\$ 32.76$ using a $30 \%$ IMD adjustment, compared to petitioners' low-end DCF valuation of $\$ 33.70$ based on management projections).

${ }_{198}$ Hamermesh \& Wachter, supra note 2, at 158-63.

199 See Del. Open MRI Radiology Assocs. v. Kessler, 898 A.2d 290, 314 (Del. Ch. 2006).

210 Hamermesh \& Wachter, supra note 2, at 165. 
ued than noncontrol ("minority") blocks, Delaware judges and lawyers may have been led to believe that shares, even in liquid and informed markets, trade at a "minority discount," and that this "discount" understates the going concern value of the corporation. That logic fails, however, because control share blocks are valued at a premium due to particular rights and opportunities associated with control, elements of value that cannot fairly be viewed as belonging either to the corporation or its shareholders. In corporations with widely dispersed shareholdings, the firm is subject to agency costs that must be taken into consideration in determining going concern value. A controlblock-oriented valuation that fails to deduct such costs does not represent the going concern value of the firm. As a matter of generally accepted financial theory, on the other hand, share prices in liquid and informed markets do generally represent that going concern value, with attendant agency costs factored or priced in. We acknowledge that share prices on any given day may fail to represent that value accurately, but we claim that there is no evidence that such prices systematically and continuously err on the low side.

Given the lack of serious support for the IMD in finance literature, we suggest that the Delaware courts may be relying on the IMD for unstated policy reasons-namely, as a means to avoid imposing upon squeezed-out minority shareholders the costs of fiduciary misconduct by the controller. That is a concern with which we sympathize. If that is the concern, however, the Delaware courts can address it in a manner that is both more comprehensive and more consistent with financial theory. Specifically, where either past or estimated future earnings or cash flows are found to be depressed as a result of fiduciary misconduct, or where such earnings or cash flows fail to include elements of value that belong to the corporation being valued, the appropriate way to address the corresponding reduction in the determination of "fair value" is by adjusting those company earnings or cash flows upward.

The Delaware courts have already expressed a willingness to make such adjustments on a case-by-case basis by determining fair value using a DCF analysis. Likewise, they have properly refused to adjust DCF valuations routinely upward on the basis of some perceived IMD associated with publicly traded shares. Therefore, because comparable company market multiple analysis is merely a simplified form of DCF analysis, the Delaware courts should be willing to adjust the subject company's earnings or cash flow measures prior to applying the market multiple so as to compensate for control shareholder or manage- 
rial misconduct-without routinely adjusting every observed trading multiple in comparable public companies on the basis of an IMD.

This approach to the problem of controller opportunism is more direct, more comprehensive in its application, and more in keeping with prevailing financial principles than the IMD that the Delaware courts have recently applied in the limited context of comparable company analysis. We submit that the Delaware courts can, therefore, comfortably dispense with resorting to the financially unsupported concept that liquid and informed share markets systematically understate going concern value. 